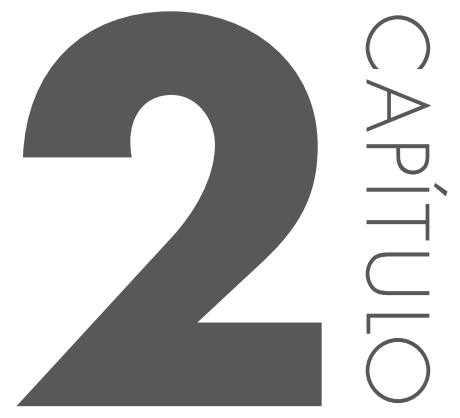

\title{
Revisão de liferatura e referencial teórico
}

Neste capítulo, são abordados os tópicos centrais desta tese, com o objetivo de embasar teoricamente seus conceitos. Subdividiu-se em Política industrial; competitividade; inovação tecnológica; setor de autopeças; Business Intelligence (BI) e panorama econômico: Brasil, Alemanha, Estados Unidos, Coreia do Sul, Índia, Rússia, China e África do Sul, baseado no Relatório de Competitividade Global da WEF.

\subsection{Política industrial}

Antes de discorrer sobre política industrial é importante conceituar crescimento e desenvolvimento econômico. Para Passos e Nogami (2003), crescimento econômico significa o crescimento da capacidade produtiva de uma economia no decorrer do tempo, medido pelo aumento no Produto Nacional Bruto (PNB) ou do produto per capita em um determinado período. O desenvolvimento econômico inclui o crescimento econômico, visando melhorias na qualidade de vida da população e infraestrutura ao longo do tempo e, nesse caso, o mais importante para o futuro do país.

Para conceituar o PNB, é fundamental conhecer o significado do Produto Interno Bruto (PIB). Há o PIB total, sendo este a soma de todos os bens e serviços produzidos em um período, dentro de um determinado país, expresso em valores monetários, representando o crescimento econômico. O PIB per capita (ou renda per capita) é obtido pelo PIB de um país dividido pelo seu número de habitantes, representando o grau do seu desenvolvimento econômico (PASSOS; NOGAMI, 2003). 
O PNB é composto do PIB mais recursos recebidos do exterior (empresas brasileiras e brasileiros que produzem e trabalham no exterior, respectivamente, e remetem recursos para o país) menos recursos enviados ao exterior (empresas estrangeiras e estrangeiros que produzem e trabalham no país, respectivamente, e enviam recursos para o seu país matriz).

Ao analisar e identificar os fatores de produção do país, as questões de eficiência produtiva e eficácia alocativa devem ser consideradas, uma vez que elas derivam de duas questões-chave para a economia: o emprego de recursos escassos e a escolha entre fins alternativos. Eficiência significa maximizar o emprego de recursos e eficácia significa otimizar as escolhas sobre o quê e quanto produzir.

Para Costa Neto e Canuto (2010), a eficácia está ligada ao bom resultado global da organização, deve-se ainda, manifestar em nível estratégico e pode-se considerar decisões ou ações eficazes como aquelas em que se fazem as coisas certas. Já a eficiência está ligada à boa utilização dos recursos disponíveis e à ideia de produtividade, então deve se manifestar em níveis tático e operacional. Pode-se também considerar que decisões ou ações eficientes são aquelas em que se fazem coisas de maneira correta. Esses conceitos estão ilustrados na Figura 2.1.

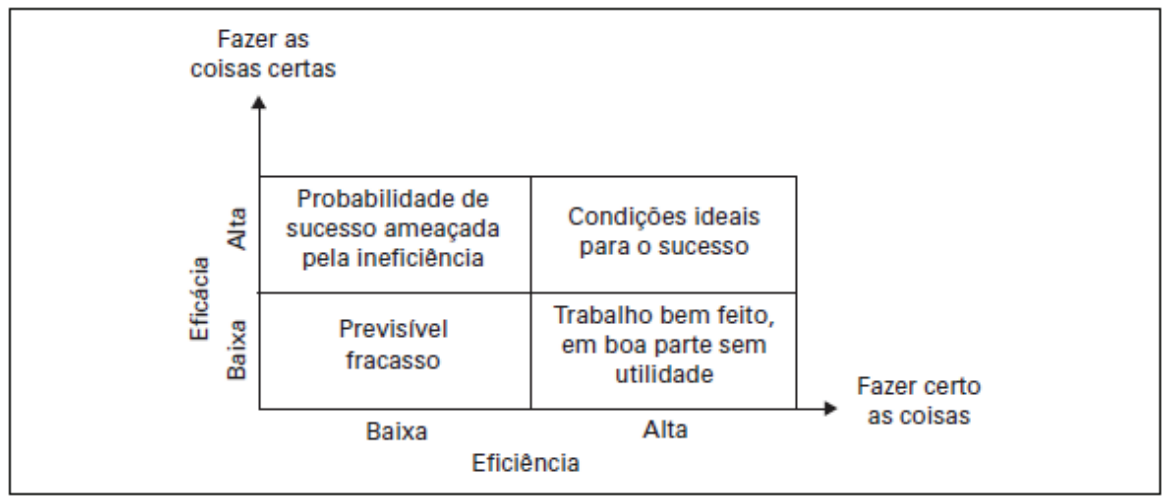

Figura 2.1 - Eficiência e Eficácia. Fonte: Costa Neto e Canuto, 2010.

Para Fleury e Fleury (2004), a política industrial constitui parte de um sistema complexo do desenvolvimento econômico sustentável, cada vez mais aberto à competição no mercado global. Embora destacando esse conceito, os mesmos autores ressaltam uma frase do ex-ministro da Fazenda, Pedro Sampaio Malan, durante o governo do presidente Fernando Henrique Cardoso, que "a melhor política industrial é não ter política industrial” (FLEURY; FLEURY, 2004, p. XX). Entretanto, caso um país não queira dar prioridade à política industrial, deve-se ter controle austero na política econômica - monetária, fiscal e cambial. 
Para Ming (2013), após o período dos governos militares, o governo da presidente Dilma Rousseff (2011-2014) foi o que mais acreditou na eficácia da política industrial, mas sem muito êxito. Enquanto os governos militares criaram reservas de mercado, intensificando o protecionismo, o governo do presidente Fernando Henrique Cardoso (1995-2002) enfatizou que o mais importante era não ter política industrial, mas, sim, fortalecer os fundamentos da economia. O governo do presidente Luiz Inácio Lula da Silva (2003-2010) se iniciou com o pensamento do governo anterior, mas aos poucos foi estimulando a atividade industrial. Já o governo da presidente Dilma Rousseff se deteve mais na proteção à indústria, destinando maiores recursos públicos para o Banco Nacional de Desenvolvimento Econômico e Social (BNDES) e para a Caixa Econômica Federal (CEF).

A política industrial tem um sentido amplo, que inclui desde vários tipos de medidas de suporte às indústrias nascentes, políticas comerciais, de ciência, de tecnologia e de competitividade setorial, encomendas públicas e políticas que afetam os investimentos estrangeiros diretos e alocação de recursos financeiros, políticas de concorrência, entre outros (CIMOLI; DOSI; STIGLITZ, 2009).

É inegável que a política industrial traz benefícios a toda a sociedade, como a geração de emprego, de renda e de divisas, ou seja, mostra que não somente o crescimento econômico é importante, mas também o desenvolvimento econômico. Em países em que os governos participam intensamente por meio de investimentos diretos ou indiretos na produção, a definição de uma política industrial é fundamental. Conforme Ming (2013) é necessário saber o que fazer e quais escolhas tomar, com competência gerencial, por meio da criação de políticas públicas consistentes e não destinar recursos públicos com a intenção de benefício eleitoral. Para Rocha e Vendrametto (2011), percebe-se que a política industrial no Brasil significa uma questão política no âmago de sua concepção, ou seja, de interesses na manutenção do poder e em medidas paliativas de curto prazo.

Kon (1999) salienta que políticas públicas são ações ligadas à formulação de decisões tomadas pelos governos e essa intervenção, nas economias capitalistas, tem como objetivos a correção de desajustes no livre mercado, a suplementação da iniciativa privada no tocante a investimentos sociais e de infraestruturas, e a coordenação geral do êxito da política econômica.

A velocidade das informações e da maior intensidade do uso de tecnologias tornou o mundo mais dinâmico e competitivo, e, a partir da Revolução Industrial, os países se tornaram globalizados e, por consequência, as empresas e as pessoas tiveram de se atualizar e buscar alternativas de capacitação e qualificação, e, ainda, desenvolver estratégias para sobreviverem.

A primeira fase da Revolução Industrial teve início na Inglaterra, em meados do século XVIII, por conta da existência de minas de carvão mineral (fonte de energia) e minério de ferro (matéria prima) em seu território, espalhando para outros países da 
Europa. Nesse período, o capitalismo industrial teve grande impulso pelo acúmulo de capital, invenções e utilização de novos sistemas de transportes a vapor, como o ferroviário e marítimo. A mudança do sistema de produção artesanal para o industrial organizou o trabalho nas fábricas e os seus trabalhadores recebiam salários baixos, enfrentavam péssimas condições de trabalho e não tinham direitos trabalhistas. Houve o uso de mão de obra infantil e feminina, com salários abaixo dos homens, e a utilização do neocolonialismo pela a busca de matérias primas e mercados consumidores na África e Ásia.

Na segunda fase, final do século XIX e começo do século XX, os Estados Unidos converteram-se no país central da economia mundial. Houve a criação e uso de novas tecnologias, como os veículos automotores e aviões, e também um significativo aperfeiçoamento nos sistemas de produção e nas tecnologias usadas nas máquinas industriais, que se tornaram mais eficientes, resultando em maior produtividade com redução de custos. Aliados a isso houve o uso do petróleo e da energia elétrica como fontes de energias principais e avanços na área de telecomunicações como, por exemplo, o telefone e o rádio.

$\mathrm{Na}$ terceira fase, liderada também pelos Estados Unidos, teve início com o final da Segunda Guerra Mundial (meados do século XX) e com a introdução do uso de novas fontes de energia, a nuclear. Logo após a guerra, surge um novo cenário nas relações econômicas e formas de produção. Há uma velocidade maior na tecnologia e inovação, acompanhados da globalização, com destaque para setores como informática, genética e biotecnologia, além da internet, melhorias nas condições de trabalho e ampliação dos direitos trabalhistas. Houve o fortalecimento do sistema capitalista com o crescimento econômico também do Japão e da Alemanha (Ocidental), que passaram a figurar como potências econômicas e, posteriormente, alguns países emergentes surgem como potenciais economias globais, como Brasil, Rússia, Índia, China e África do Sul (BRICS).

A Revolução Industrial foi importantíssima para o desenvolvimento de tecnologias utilizadas atualmente, porém, trouxe também questões relevantes e de impactos com as preocupações com o meio ambiente, tornando-se tema de maior relevância nos países e de exigências para as empresas na questão de gestão ambiental, inclusive na criação do ISO14000, que é um conjunto de normas que definem parâmetros e diretrizes para a gestão ambiental para as empresas (privadas e públicas).

A ISO (International Organization for Standardization ou Organização Internacional para Padronização, em português) é uma entidade de padronização e normatização, criada em Genebra, na Suíça, em 1947, com o objetivo de aprovar normas internacionais em todos os campos técnicos, como normas técnicas, classificações de países, normas de procedimentos e processos. No Brasil, a ISO é representada pela ABNT (Associação Brasileira de Normas Técnicas). 
Dentro do aspecto histórico, o Brasil iniciou seu desenvolvimento industrial no final do século XIX, em especial em 1885, com o surgimento do mercado de mão de obra assalariada originado pela imigração em massa, a abolição da escravatura e a intensificação da deterioração das estruturas pré-capitalistas, surgindo duas classes econômicas, sendo os empresários e os trabalhadores (LACERDA et al., 2010). Outro fator importante foi por meio dos investimentos dos cafeicultores, que faziam aportes de recursos financeiros de uma parte dos lucros que recebiam da exportação de café, principalmente em São Paulo e no Rio de Janeiro, cujos principais segmentos eram em fábricas de tecidos, calçados, entre outros, utilizando a maior parte da mão de obra de imigrantes italianos. Entretanto, devido à Grande Depressão (1929), a crise do café afugentava os capitais investidos na cafeicultura, provocando mudanças de investimentos do café para o algodão.

Outro destaque pode-se dar a Irineu Evangelista de Souza (1813 - 1889), o Visconde de Mauá, importante industrial, banqueiro e político brasileiro durante a época do Brasil Império. Irineu recebeu o título de Barão em 1854 e, posteriormente, Visconde de Mauá em 1874. As suas principais realizações foram: (1) empreendimento da construção da primeira ferrovia brasileira, construída no estado do Rio de Janeiro, ganhou o nome de Estrada de Ferro Mauá; (2) fundação da Companhia de Iluminação a Gás do Rio de Janeiro; e (3) fundação da Companhia de Navegação a Vapor do Amazonas (CALDEIRA, 2000).

Lauerhass Jr. (1986) comenta que na primeira Era Vargas (1930-1945), a indústria brasileira ganhou novo impulso, privilegiando as indústrias nacionais, com a intenção de evitar a dependência externa. Nesse período, houve a regulamentação do mercado de trabalho, medidas protecionistas e investimentos em infraestrutura, mas esse desenvolvimento no país ainda continuou restrito às grandes cidades. Um aspecto relevante nessa época foi o fim da Segunda Guerra Mundial (1939-1945), oportunidade para o Brasil exportar seus produtos industrializados, uma vez que as indústrias da Europa estavam arrasadas. Essa situação provocou ondas migratórias do campo para as cidades, fazendo surgir um expressivo contingente de trabalhadores urbanos, ou seja, operariado e classe média.

$\mathrm{Na}$ segunda era do governo Vargas (1951-1954), houve a necessidade de implementação de reformas econômicas e projetos desenvolvimentistas, não agradando a população, uma vez que esta esperava mais direitos sociais e aumento de salários. Alguns setores começaram a se organizar de forma autônoma, buscando evitar a manipulação política de líderes demagogos.

A década de 1950, possivelmente, foi um dos períodos de maior transformação no país. Em 1951, foi criada a Campanha Nacional de Aperfeiçoamento de Pessoal de Nível Superior (atual CAPES - Coordenação de Aperfeiçoamento de Pessoal de Nível Superior), pelo Decreto $n^{\circ} 29.741$, com o objetivo de assegurar a existência de pessoal especializado em quantidade e qualidade suficientes para atender às necessidades dos 
empreendimentos públicos e privados que visam ao desenvolvimento do país. Em 1952, é criado o Banco Nacional de Desenvolvimento Econômico (BNDE), por meio da Lei $n^{\circ} 1.628$, e teve como objetivo da nova autarquia federal ser o órgão formulador e executor da política nacional de desenvolvimento econômico (atual BNDES - Banco Nacional de Desenvolvimento Econômico e Social, alterado em 1982). A Petrobrás é criada em 1953, desencadeando melhorias no desenvolvimento de produtos ligados ao petróleo, como plásticos, fertilizantes, borracha, entre outros.

No período de 1956 a 1960, o governo do presidente Juscelino Kubitschek de Oliveira - JK - com o lema de "50 anos em 5", fez o desenvolvimento industrial brasileiro ganhar novos rumos. A economia se abre para o capital internacional, atraindo e incentivando indústrias estrangeiras, principalmente as montadoras de veículos como Ford, General Motors (GM), Mercedes-Benz, Volkswagen e Willys.

Kubitscheck (2000) comenta que era nítida a linha divisória que separava duas fases antagônicas da história do Brasil. Há um Brasil antes de 1956, afundado no marasmo econômico, descrente de si mesmo, e outro Brasil, confiante nas próprias energias, otimista, cioso da sua soberania e consciente do relevante papel que the compete representar no concerto das grandes nações.

O desenvolvimento industrial durante o plano de metas do governo de JK foi liderado pelo crescimento da produção de bens de capital e de bens de consumo duráveis. Para Lacerda et al. (2010), o crescimento industrial que ocorreu a partir do início do governo JK estava estruturado em um tripé, formado pelas empresas estatais, pelo capital privado estrangeiro e, como sócio menor, o capital privado nacional. As transformações estruturais que ocorreram na segunda metade dos anos 1950 resultaram na consolidação da oligopolização da economia brasileira.

Nas décadas de 1970, 1980 e 1990, a industrialização do Brasil continuou a crescer, embora, em alguns momentos de crise econômica, esteve estagnada, por causa de períodos de inflação e hiperinflação, em destaque a década de 1980, a chamada década perdida.

Reis Velloso (1992) esclarece que entre 1970 e 1973, auge do chamado milagre econômico, a poupança do governo era de $6,6 \%$ do PIB, porém, foi declinando continuamente, conforme aumentava a instabilidade externa, até tornar-se negativa em 1985 e em $2 \%$ do PIB em 1988.

A instituição do I Plano Nacional de Desenvolvimento (I PND), pela Lei 5.727 de 04/11/1971, incluindo ainda o Programa Metas e Bases para a Ação de Governo (1970-1974), tinha como principal objetivo preparar a infraestrutura necessária para o desenvolvimento do Brasil nas décadas seguintes, com ênfase em setores como transportes e telecomunicações, além de prever investimentos em ciência e tecnologia e a expansão das indústrias naval, siderúrgica e petroquímica. Para isso, articulava empresas estatais, bancos oficiais e outras instituições públicas na elaboração de políticas setoriais, deixando clara a intervenção do governo. Nesse período fizeram 
parte do I PND grandes obras de infraestrutura, como a usina hidrelétrica de Itaipu, a Ponte Rio-Niterói e a rodovia Transamazônica.

Conforme Silveira e Rathmann (2007), nos primeiros anos do governo do general Emílio Garrastazu Médici (1969-1974), as metas propostas por João Paulo dos Reis Velloso e Mário Henrique Simonsen foram atingidas, com crescimento médio de $11,2 \%$ ao ano (chegando a 13,9\% em 1973), e inflação média abaixo de 19\%.

O I PND foi interrompido por causa da crise do petróleo de 1974 e forçou uma mudança de rumo na economia, levando o presidente general Ernesto Geisel (19751979), sucessor do presidente general Emílio Garrastazu Médici, a lançar o II Plano Nacional de Desenvolvimento, que tinha como finalidade estimular a produção de insumos básicos, bens de capital, alimentos e energia. A sua proposta era de realizar um ajuste estrutural na economia brasileira.

Importante salientar que há diferença entre ajuste estrutural e ajustes conjunturais. Enquanto estes se referem a medidas de regulação da economia ou de gestão da política econômica no curto prazo (por meio da utilização instrumentos tais como taxa de câmbio, taxa básica de juros, regras para exportação e importação, tributação, entre outros), o ajuste estrutural tem como objetivo reorganizar as bases da economia.

O II PND foi uma resposta à crise econômica decorrente do primeiro choque do petróleo, no fim do chamado "milagre econômico brasileiro", período de seis anos consecutivos com taxas de crescimento superiores a $10 \%$ ao ano. Esse Plano era extremamente ambicioso e visava enfrentar os problemas advindos da crise, sendo praticamente o último grande plano econômico do ciclo desenvolvimentista e provavelmente, o mais amplo programa de intervenção estatal na economia do país. (MANTEGA, 1997)

Segundo Lacerda et al. (2010), o plano buscava a redução da dependência do petróleo árabe, por meio do investimento em pesquisa, prospecção, exploração e refinamento de petróleo dentro do Brasil, e o investimento em fontes alternativas de energia, como o álcool e a energia nuclear. Além desse aspecto, também buscou dominar todo o ciclo produtivo industrial ao investir pesadamente na produção de insumos básicos e bens de capital.

O sucesso do II PND dependia de grande volume de recursos e de financiamento a longo prazo e a maior parte desses financiamentos foi conseguida com os petrodólares e as linhas públicas de crédito, oferecidas pelo BNDE, mas não foi bem-sucedido, mesmo com investimentos por meio do capital financeiro nacional e das oligarquias, aumentando de forma considerável à dívida externa do Brasil. Embora para BresserPereira (1983) o plano tenha conseguido êxito parcial, uma vez que, pela primeira vez na história, o Brasil conseguiu dominar todo o ciclo produtivo industrial, essa industrialização ocorreu a um preço alto, que fez a dívida externa explodir, resultando na moratória, no início de 1987, no governo do presidente José Sarney de Araújo Costa. 
A abertura para as importações no governo do presidente Fernando Affonso Collor de Mello (1990-1992) provocou uma profunda reestruturação industrial no Brasil, trazendo benefícios para os consumidores pela maior disponibilidade de bens e serviços, com melhores preços e tecnologia, embora com impactos negativos sobre o nível de emprego, observou-se que houve prejuízo aos produtores locais com tributação e juros elevados, carência de infraestrutura e excessiva burocracia, o que não ocorreu com os produtores estrangeiros (LACERDA et al., 2010).

Nesse mesmo período, foi criada a nova Política Industrial e de Comércio Exterior (PICE), que tinha como objetivo central o aumento da eficiência na produção e comercialização de bens e serviços, com base na modernização e reestruturação da indústria.

Segundo Guimarães (1996), as estratégias da PICE eram:

a) Redução progressiva dos níveis de proteção tarifária, eliminação da distribuição indiscriminada e não transparente de incentivos e subsídios e fortalecimento dos mecanismos de defesa da concorrência;

b) Reestruturação competitiva da indústria mediante a adoção de mecanismos de coordenação, de instrumentos de apoio creditício e de fortalecimento da infraestrutura tecnológica;

c) Fortalecimento de segmentos potencialmente competitivos e desenvolvimento de novos setores, por meio de maior especialização da produção;

d) Exposição da indústria à competição internacional, visando maior inserção no mercado externo, melhoria de qualidade e preço no mercado interno e aumento da competição em setores oligopolizados;

e) Capacitação tecnológica da empresa nacional, por meio de proteção tarifária seletiva às indústrias de tecnologia de ponta e do apoio à difusão das inovações nos demais setores.

Para atingir essas estratégias, foram criados dois mecanismos: o Programa de Competitividade Industrial (PCI) e o Programa Brasileiro de Qualidade e Produtividade (PBQP).

Lacerda et al. (2010) ressaltam que o BNDES teve um papel primordial no processo, definindo um modelo de desenvolvimento denominado integração competitiva, baseado nos conceitos de competitividade e produtividade, desvinculadas de políticas setoriais. O BNDES também foi indicado como gestor do Programa Nacional de Desestatização.

Nardini (1990) destaca que o BNDES priorizava três focos de investimentos:

a) Modernização da estrutura produtiva existente, incluindo melhorias tecnológicas em unidades instaladas, substituição de processos e de unidades produtivas obsoletas, aplicação de sistemas de automação industrial e de controle de processo, introdução de novos produtos, reestruturação de modelos de comercialização e de administração técnica e financeira e estímulo a associações entre empresas. 
b) Ampliação da capacidade produtiva por meio de expansões e novas instalações em setores de bens de consumo e de insumos básicos. Os investimentos visavam atender a demanda interna e externa paralelamente à modernização dos processos produtivos.

c) Investimentos nos setores de infraestrutura, particularmente nos setores de energia elétrica, transportes e portos. Previa-se a ampliação da participação de capitais privados em atividades antes sob a responsabilidade estatal.

O Plano Real (1994) estabilizou a economia brasileira, embora tenha permitido o país ter uma base industrial melhor, produzindo diversos produtos como automóveis, máquinas, roupas, aviões, equipamentos, produtos alimentícios industrializados, eletrodomésticos, entre outros, a indústria nacional ainda continua dependente da tecnologia externa. (LACERDA et al., 2010)

Conforme Kupfer e Hasenclever (2002), a política industrial deve ser entendida como o conjunto de incentivos e regulações associadas a ações públicas, que podem afetar a alocação inter e intra industrial de recursos, influenciando a estrutura produtiva e patrimonial, a conduta e o desempenho dos agentes econômicos em um determinado espaço nacional. Pretende-se aumentar a capacidade produtiva e competitiva das empresas e setores.

Os autores ainda destacam que na visão neoclássica o objetivo do mercado competitivo é a alocação eficiente dos recursos. A livre mobilidade dos fatores e o atomismo dos agentes levam a que o mecanismo de demanda e oferta determine preços de equilíbrios ótimos do ponto de vista social, significando que qualquer aumento extra na utilidade de um grupo específico somente pode ser atingido a expensas da utilidade de outro grupo.

Pode-se dizer que o produto industrial brasileiro não é, muitas vezes, competitivo no exterior devido à burocracia, a elevada carga tributária e o câmbio, e como consequência, os exportadores perdem mercados e escala de produção, e, ainda, têm dificuldades de atender ao mercado doméstico com eficácia.

Conforme o relatório da Organização das Nações Unidas para o Desenvolvimento Industrial (ONUDI, 2013), a produção industrial brasileira manteve-se moderada no primeiro trimestre de 2013 , com aumento de $1,6 \%$, porém, inferior ao comparar com as outras economias emergentes que apresentaram resultados melhores, como, por exemplo, a Índia, 2,5\%, Indonésia, 4,5\% e Turquia, 4\%. O relatório ainda ressalta que no Brasil a fabricação enfrentou a alta inflação e forte concorrência de produtos importados mais baratos, o que resultou em déficits comerciais elevados.

Kupfer e Hasenclever (2002) destacam, de forma geral, quatro pontos principais de discussão sobre a política industrial. $\mathrm{O}$ primeiro, aponta que não é relevante discutir a intensidade de intervenção, mas os seus propósitos. O segundo ponto enfatiza as relações próximas entre política industrial e outras políticas econômicas, 
principalmente aquelas de caráter macroeconômico. No terceiro ponto, a literatura econômica diverge, em termos da necessidade de ações estatais, do tipo de política industrial e quanto a seus objetivos, quais medidas públicas devem ser adotadas para promover a concorrência, o desenvolvimento tecnológico e o que é necessário para minimizar efeitos negativos da atividade industrial. Por fim, o quarto e último ponto é a análise concreta de experiências nacionais, regionais ou setoriais, que demanda uma avaliação criteriosa da competência do Estado para exercer um papel proativo para sociedade.

Campanário e Silva (2004) comentam que a política industrial pode ser entendida como a criação, a implementação, a coordenação e o controle estratégico de instrumentos destinados a ampliar a capacidade produtiva e comercial da indústria, com intuito de garantir condições concorrenciais sustentáveis nos mercados interno e externo. Ressaltam, como novo desafio, que a agenda ortodoxa refratária a qualquer política industrial pode e deve ser substituída por um caminho em que as questões institucionais e normativas para um novo desenho do papel do Estado sejam amplamente discutidas.

Almeida (2009) destaca o dilema entre optar-se por uma política industrial mais voltada ao fomento e à inovação, ou uma política industrial mais pragmática e multissetorial, sendo uma dificuldade das políticas industriais modernas não apenas no Brasil, mas também nos demais países da América Latina.

Além do referido dilema, as empresas brasileiras têm passado por um forte processo de internacionalização, considerando que não existe, no papel, uma política de discriminação entre empresas de capital nacional e estrangeiro.

Embora se aceite essa discriminação na formação de empresas nacionais líderes, no caso dos incentivos à Pesquisa, Desenvolvimento e Inovação (P, D \& I), não há uma estratégia de fomento específica para empresas brasileiras como meio de facilitar o processo de recuperação - denominada de catching up - tecnológico das empresas domésticas em relação à fronteira de produção, principalmente naqueles setores mais intensivos em tecnologias.

Uma questão que está em discussão é se no Brasil está havendo um processo de desindustrialização. Para Guardado e Bolle (2013), há evidências de que o mercado de trabalho no Brasil alcançou nível de saturação, operando próximo dos patamares de pleno emprego, preocupações com alta carga tributária, queda nos investimentos, levando às medidas de desoneração tributária e sendo necessário expandir os mercados para as empresas, derrubando as fronteiras que limitam operações apenas no mercado doméstico, na maioria das vezes, provoca efeito final nulo.

O conceito clássico de desindustrialização foi introduzido por Rowthorn e Ramaswany (1999), como sendo uma redução persistente da participação do emprego industrial no emprego total de um país ou região. Os países desenvolvidos teriam passado por um forte processo de desindustrialização a partir da década de 1970 e a América Latina teria passado pelo mesmo processo na década de 1990. 
Posteriormente, Tregenna (2009) redefiniu de forma mais ampla o conceito clássico de desindustrialização, como sendo uma situação em que tanto o emprego industrial como o valor adicionado da indústria se reduzem como proporção do emprego total e do PIB, respectivamente. Bacha e Bolle (2013) comentam que no Brasil o debate sobre desindustrialização teve início em seguida à abertura comercial no começo dos anos 1990 e foi revisitado diversas vezes. Além disso, há três possíveis hipóteses a respeito da causa da desindustrialização.

Na primeira, devido à apreciação cambial, o Brasil contraiu a “doença holandesa”. Conforme Bresser-Pereira (1983), esse conceito é uma falha de mercado fundamental, que se origina na existência de recursos naturais ou humanos, baratos e abundantes, que mantêm a taxa de câmbio apreciada por um tempo indeterminado e impede a produção de bens comercializáveis, usando tecnologia no estado da arte. Dessa forma, provoca um obstáculo ao crescimento ao lado da demanda agregada, pois limita as oportunidades de investimento. Para Nassif (2008), as evidências empíricas não confirmam uma "nova doença holandesa" no Brasil, uma vez que não se percebeu realocação generalizada de fatores produtivos para os segmentos baseados em recursos naturais, e o retorno acentuado da especialização exportadora em produtos intensivos, em recursos naturais ou em trabalho.

A segunda avaliação considera que a economia brasileira pode estar se curando de uma "doença soviética", em que, ao passar por um processo de abertura, a indústria se tornou menor e mais eficiente. Segundo Almeida (2012), esse conceito sob o aspecto econômico é quando se avalia a questão pelo ângulo do PIB per capita, que no caso do Brasil, na década de 1970, tinha uma participação da indústria maior que outros países.

$\mathrm{Na}$ terceira hipótese, Bacha e Bolle (2013) afirmam que o problema não é específico do setor industrial, mas afeta a produtividade da economia como um todo, em consequência dos baixos níveis de poupança e investimento e da alta tributação.

Ainda não está claro como o governo brasileiro conseguirá conciliar a política de promoção de competitividade de curto prazo, baseada na construção de empresas líderes nos setores de baixa e médio-baixa tecnologia, com uma política industrial mais voltada ao fomento à pesquisa e inovação. Também ainda não está evidente, no contexto da atual política industrial brasileira, de que forma as empresas nacionais conseguirão se aproximar da fronteira de produção, uma vez que os incentivos à inovação são também apropriados por empresas multinacionais de propriedade de não residentes. Provavelmente essas duas questões sejam os dois principais dilemas da atual política industrial do Brasil.

Para buscar respostas as essas questões, pode-se citar Kim (2005), que faz analogia com a economia sul-coreana, citando quatro fatores de diferenciação: (1) a grande intervenção do governo na economia; (2) a concentração econômica em torno das grandes corporações (os chaebols); (3) a preservação da cultura e do idioma nacionais 
e (4) a organização militarista e verticalizada das empresas sul-coreanas.

Essas mudanças de comportamento, mesmo de forma gradativa, podem contribuir para melhorias no desempenho do Brasil.

\subsection{Competitividade}

Com o mercado globalizado, uma questão fundamental é a competitividade, pois a penetração em outros mercados é necessária para criar novas oportunidades de crescimento e contribuir com o país.

O mercado competitivo é aquele que possui muitos compradores e vendedores negociando produtos idênticos, de modo que cada comprador e vendedor é um tomador de preço (MANKIW, 2012).

Conforme Porter (2004), a competitividade é vista e compreendida sob diversas óticas, podendo ser atribuída conforme o panorama macroeconômico, impulsionado por variáveis, como taxas de câmbio e de juros, déficits e políticas governamentais, baixos dispêndios com força de trabalho, recursos naturais, e, acima de tudo, diferenças de práticas administrativas.

Contador (2003) comenta que para um país tornar-se competitivo, suas empresas precisam alcançar elevada produtividade. Sendo assim, a competitividade pode ser entendida como a capacidade da empresa de formular e implementar estratégias simultâneas que lhes permitam conservar, de forma duradoura, uma posição sustentável no mercado, ou seja, um caráter sistêmico (ZACCARELLI; GUIMARÃES, 2007).

Os autores ainda ressaltam que a competitividade está diretamente atrelada à obtenção de vantagem competitiva, seja pelo valor que a empresa consegue estabelecer para seus produtos e serviços e da forma que ele é percebido pelos clientes, ou pela diferenciação. De acordo com Costa Neto e Canuto (2010), para a empresa ser competitiva, deve poder oferecer seus produtos ou serviços com a qualidade esperada pelos clientes e com preços aceitáveis pelo mercado e, para ter preços competitivos, a empresa deve ter custos compatíveis, o que exige produtividade no uso dos recursos de que dispõe.

A Qualidade e a Produtividade destacam-se como elementos constituintes da Competitividade, conforme Figura 2.2. 


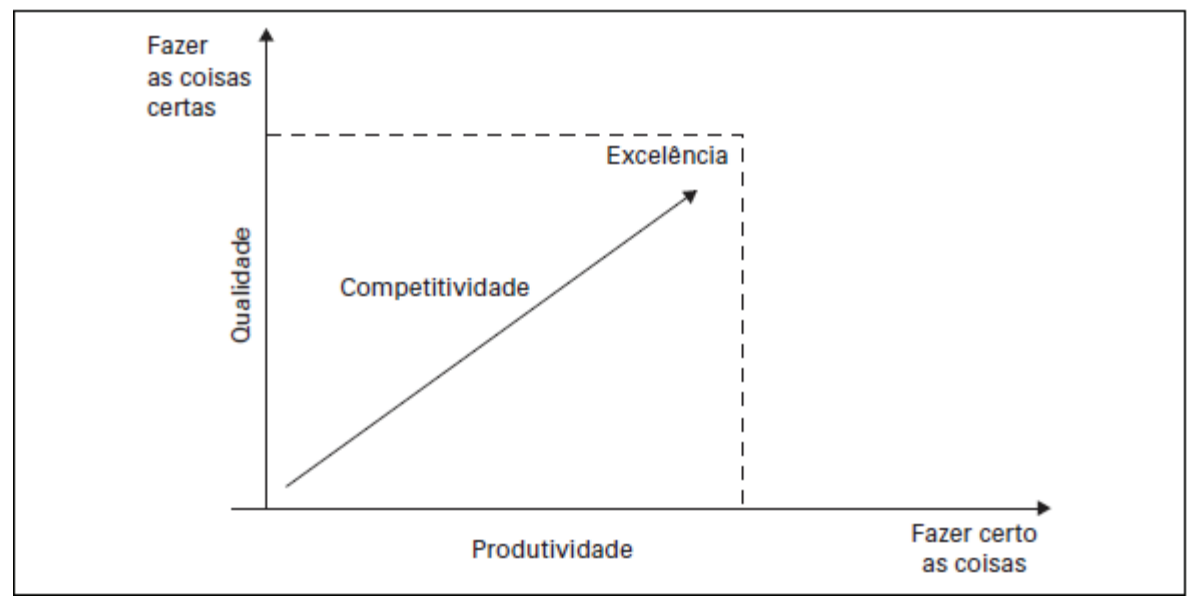

Figura 2.2 - Qualidade, Produtividade e Competitividade. Fonte: Costa Neto e Canuto, 2010.

Para Kon (1999), a busca de novos mercados, seja voltada para o mercado interno ou externo, deve contemplar a escolha de investimentos em setores selecionados que se traduzam em alguma vantagem comparativa.

Porter (2004) ainda considera os fatores estruturais como alavancadores de vantagens competitivas, conceituando as cinco forças competitivas, a saber: (1) a entrada de novos concorrentes; (2) a ameaça de produtos ou serviços substitutos; (3) o poder de negociação dos compradores; (4) o poder de negociação dos fornecedores e (5) a rivalidade entre os concorrentes.

Contador (2008) criou um modelo para competitividade, denominado de Campos e Armas de Competição (CAC), enfatizando que para a empresa ser competitiva, não há condição mais relevante do que ter alto desempenho apenas naquelas poucas armas que lhe dão vantagem competitiva nos campos da competição escolhidos, para cada par produto/mercado.

Pelo modelo CAC existem quatro condicionantes da competitividade, a saber: (1) produto adequado ao mercado a qual se destina; (2) escolha adequada dos campos da competição e dos coadjuvantes para cada produto/mercado; (3) uso adequado das armas da competição, o que significa identificar as armas que são relevantes, semirrelevantes e irrelevantes para os campos da competição e para os coadjuvantes, e definir a intensidade dessas armas; e (4) alinhamento das armas aos campos da competição e aos coadjuvantes.

Zaccarelli e Guimarães (2007) relacionam competitividade com a atratividade de áreas estratégicas, oferecendo uma ponderação às empresas que trabalham com um portfólio diversificado de produtos e serviços, em múltiplas áreas de atuação.

Para Ferraz, Kupfer e Haguenauer (1997), ao invés de entendida como uma característica intrínseca de um produto ou de uma firma, a competitividade surge 
como uma característica extrínseca, relacionada ao padrão de concorrência vigente em cada mercado. As empresas mais competitivas respondem com a constante introdução de inovações de produtos, buscando atender mercados e clientes mais exigentes, e com reduções de preços.

São consideradas de alta atratividade as áreas com boas perspectivas de crescimento, baixa concorrência aliada à dificuldade na entrada de novos concorrentes, bom retorno sobre os investimentos, baixa turbulência, bons canais de distribuição, entre outros. Por outro lado, são consideradas de alta competitividade as áreas onde a empresa se destaca no mercado como uma das primeiras opções entre os fornecedores que concorrem naquela área de negócios.

Um modelo de competitividade em destaque é chamado "O Diamante de Porter", que busca ampliar a análise da competitividade com foco no entendimento do porque empresas de um determinado país são capazes de competir com maior sucesso contra empresas de outros países, envolvendo tanto a produção local quanto as exportações. O modelo analisa quatro aspectos essenciais para a capacidade competitiva de uma empresa, conforme Figura 2.3.

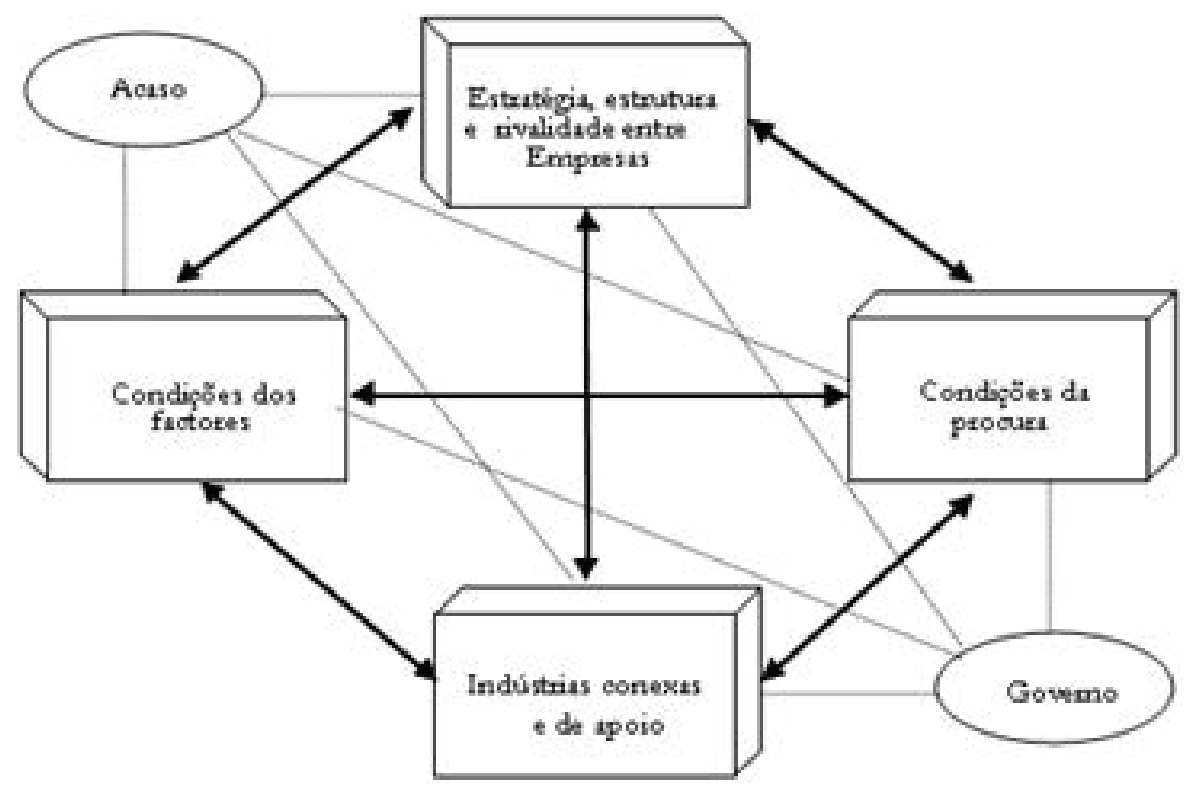

Figura 2.3 - Diamante de Porter. Fonte: Porter, 1993.

Partindo desse modelo "diamante", pode-se perceber que há um ciclo para a obtenção de vantagens competitivas. O benefício angariado em um determinante faz surgir ou aprimorar vantagens em outros, gerando externalidades territoriais positivas. Além disso, o governo pode implementar políticas favoráveis ou desfavoráveis, incidindo direta ou indiretamente em cada um dos determinantes. Nos casos fortuitos 
são frutos do acaso, sobre os quais as empresas não têm controle e podem induzir processos que resultam em modificações profundas nas indústrias (ALVES, 2010).

A ideia de competitividade entre as empresas pode levar a um conceito errôneo de disputa de tal magnitude que se torna, em alguns casos, uma guerra. Contudo, deve-se levar em consideração que ao analisar cenários quando as empresas se unem, ficam mais fortes.

Para Schumpeter (1997), a rivalidade traz benefícios não só por levar novos mercados ou tecnologias ao conhecimento das empresas, mas também por adotar uma postura mais agressiva diante de seus rivais, modificando assim a fundamentação da concorrência, por meio de um processo evolutivo que permite o êxito da competitividade na organização.

A concorrência é um processo de disputa fundamental em uma sociedade de mercado em que o produtor não sabe de antemão qual a quantidade de seus bens o mercado está disposto a absorver ao preço estipulado. (POSSAS, 2006)

Conforme Garcia (2006), a presença concentrada de empresas de um mesmo setor ou segmento industrial é capaz de gerar externalidades positivas, que são apropriadas pelas firmas, incrementando sua capacidade competitiva.

Outra questão dentro da competitividade são os impactos dos custos de produção, podendo provocar ineficiência dos processos, gargalos, restrição na capacidade produtiva e gerar desempregos. Pindyck e Rubinfel (2002) comentam sobre a minimização de custo e como a teoria da empresa baseia-se na suposição de que as empresas escolhem para seus processos produtivos, os insumos capazes de minimizar o custo da produção.

Contador (2003) ressalta que, pela teoria microeconômica, o lucro máximo ocorre quando a receita marginal se iguala ao custo marginal. A empresa tem condições para levantar a curva dos custos, por serem seus componentes conhecidos. Mas, construir a curva de receita é extremamente difícil, pois depende das relações entre o preço e demanda, e, sobre esta, a empresa tem pouco domínio.

Competir em custo de produção é diferente de competir em preço do produto. Não obstante as armas serem as mesmas, o objetivo é outro, ou seja, competir em custo é uma arma e não um campo de competição. Na competição em preço, a empresa visa maior participação de mercado pela autolimitação dos valores cobrados pelos seus produtos (CONTADOR, 2008).

O planejamento das atividades e dos processos fica evidente e torna-se imprescindível acompanhar e controlá-los. Para Ferraz, Kupfer e Haguenauer (1997), as empresas mais competitivas respondem com a constante introdução de inovações de produtos, buscando atender mercados e clientes mais exigentes e com reduções de preços.

O Relatório da Confederação Nacional da Indústria (CNI, 2012), que analisa a Competitividade Brasil 2012, mostra que o aumento da competitividade é o maior 
desafio do Brasil. Dentre os 14 países avaliados, o Brasil ocupa a $13^{a}$ posição, ficando à frente apenas da Argentina. Ele situa-se no grupo de países menos competitivos em seis dos oito fatores condicionantes da competitividade, e na sétima posição em 13 países (grupo intermediário) no fator tecnologia e inovação, mas percebe-se que nesse fator não há desenvolvimento, mas sim o seu acesso, ou seja, a sua compra, e no grupo superior, quarta posição, no fator de disponibilidade e custo da mão de obra, sendo esse, o indicador que leva em conta o comportamento da oferta de mão de obra.

A Educação também pode ser considerada um ponto de competitividade, pois a disseminação e a sua qualidade provocam diferença nos resultados. O planejamento e estratégia nos gastos do governo são importantes, uma vez que não é somente o valor destinado que conta, mas sim a eficácia da sua utilização. O mesmo relatório da CNI (2012) ainda ressalta que o Brasil se situa na penúltima posição entre os nove países considerados nesse subfator. Em ordem de disseminação da Educação: Coreia do Sul, Austrália, Rússia, Canadá, Espanha, Chile, Polônia, Brasil e México. O Brasil ocupa uma posição relativa favorável no tocante ao volume de matrículas no ensino médio, mas recuou do estrato intermediário para o inferior no caso da educação superior, refletindo a ocorrência de um volume significativo de abandono de cursos em ambos os níveis de ensino. Esse relatório da CNI e seus 10 Fatores Chaves são apresentados mais detalhados no Capítulo 3 desta tese, intitulado Metodologia.

A estratégia de criar uma área para treinar e desenvolver profissionais é uma das alternativas para reduzir esse conflito. O governo pode subsidiar e as empresas operacionalizar. Segundo Ferraz, Kupfer e Haguenauer (1997), as empresas brasileiras dispõem de profissionais nas altas e médias gerências com níveis de qualificação comparáveis aos das empresas líderes mundiais. Mas, devido à introdução de novas técnicas organizacionais e automação de base microeletrônica nas plantas industriais, a qualificação de parte dos trabalhadores está se tornando inadequada. Os autores enfatizam que a partir de uma perspectiva dinâmica, o desempenho do mercado e a eficiência produtiva decorrem da capacitação acumulada pelas empresas.

Embora as empresas busquem sempre os mais qualificados profissionais, sempre devem ter em mente que o capital humano é o maior responsável para buscar os resultados, ou seja, construir o lucro, e mantê-las no mercado e contribuir com o desenvolvimento do país.

Um fato que se pode destacar foi a desaceleração projetada para o segundo semestre de 2010 e a sufocante perda de competitividade frente aos importados, que provocaram preocupações. No início de maio de 2010, o governo federal anunciou algumas medidas para incentivar a exportação de produtos nacionais e entre elas está a suspensão do desconto no Imposto de Importação (II) de autopeças, uma vez que as montadoras tinham uma redução de $40 \%$ na importação.

Para Cano e Silva (2010), o problema é que as estratégias de desenvolvimento industrial não se fazem apenas com políticas industriais explícitas. Por melhor que seja 
seu desenho, deve contar com políticas macroeconômicas compatíveis. Do contrário, a política industrial implícita nestas últimas, anula ou distorce as primeiras.

Conforme Ming (2013), para o governo da presidente Dilma Rousseff, a falta de competitividade da indústria deve-se, em grande parte, à herança dos juros insuportáveis, ao câmbio excessivamente valorizado e à sobrecarga das contribuições sociais, porém, não caminhou muito, pois o protecionismo comercial (altas barreiras alfandegárias) esbarra com a nova realidade do suprimento global, quando o importante é usar componentes e peças de mais qualidade e preço mais baixo, independentemente de onde vierem.

Outro fato que se deve considerar é o Custo Brasil, que, conforme Zanella (2010), é o diferencial de custos entre a indústria brasileira e seus principais concorrentes internacionais, em destaques os Estados Unidos e Alemanha. É um grupo de itens que por meio de algumas dificuldades burocráticas, estruturais e econômicas, encarecem os investimentos no Brasil e o deixa mais longe do desenvolvimento econômico.

Os componentes do Custo Brasil são: (1) impostos não recuperáveis na cadeia produtiva; (2) encargos sociais e trabalhistas; (3) logística; (4) impacto dos juros sobre capital de giro; (5) burocracia e custos de regulamentação; (6) custos de investimento; (7) custos dos insumos básicos; e (8) custos de energia.

Por isso, criar medidas que não sejam simplesmente momentâneas, mas sim sustentáveis, é imprescindível para um país e para as empresas, uma vez que os mercados são cada vez mais competitivos e a flexibilidade e adaptação ocorrem de forma rápida. Assim, essas medidas se fazem necessárias, principalmente para o futuro da sua população.

\subsection{Inovação Tecnológica}

Segundo o Dicionário Escolar da Língua Portuguesa, da Academia Brasileira de Letras (2008), inovar é tornar algo novo, renovar, reformar, atualizar, ter criatividade.

Com todo o processo de globalização e a dependência cada vez maior de ideias e melhorias contínuas, a inovação se tornou imprescindível no dia a dia das pessoas, empresas e também para os países.

Conforme o Manual de Oslo (1997), inovação é a implementação de um produto (bem ou serviço) novo ou significativamente melhorado, ou um processo, ou um novo método. As suas atividades abrangem etapas científicas, tecnológicas, organizacionais, financeiras e comerciais, que conduzem ou visam conduzir, à implementação de inovações.

A inovação traz vantagens para aqueles que a utilizam e incentivam seu uso. Seus impactos vão desde uma simples melhoria em um processo ou produto até a quebra de paradigmas e comportamento das pessoas, criação de tendências de mercado e geração de vantagem competitiva. 
A inovação deve ser vista como uma oportunidade de aprendizado, oportunidade e melhoria nos processos, pois cria dinamismo e faz com que as pessoas, empresas e países deixem de ficar acomodados e busquem cada vez mais conhecimento e aperfeiçoamento e, consequentemente, melhoria na qualidade de vida e de convivência.

Quando uma inovação é percebida como difícil de ser entendida e usada, tem-se a complexidade tecnológica. Tigre (2006) ressalta que tecnologias muito inovadoras podem criar impasses no processo decisório, devido à insuficiência de informações, incertezas e riscos do pioneirismo, uma vez que a variedade de alternativas tecnológicas torna difícil a comparação entre elas e traz riscos de o usuário tornar-se dependente ou aprisionado a um determinado fornecedor.

Para Pelaez (2006), as inovações realizam-se na medida em que permitem reduzir os custos em relação aos preços existentes, mas as relações entre elas e o emprego permanecem muito incertas, na medida em que são necessariamente disseminadas pelo sistema de preços e pelo conjunto dos mecanismos macroeconômicos que determinam o nível geral das atividades.

A inovação sempre esteve no cotidiano das pessoas, empresas e nos países, porém, após a revolução industrial, a intensificação pela inovação praticamente tornou-se necessária para sobrevivência e modernidade, utilizando a inovação tecnológica de forma intensa por meio da Pesquisa, Desenvolvimento e Inovação (P, D \& I).

A inovação tecnológica, conforme Tigre (2006), constitui uma ferramenta essencial para aumentar a produtividade e a competitividade das organizações e para impulsionar o desenvolvimento econômico de regiões e países. O desenvolvimento não deriva de um mero crescimento das atividades econômicas existentes, mas reside fundamentalmente em um processo qualitativo de transformação da estrutura produtiva no sentido de incorporar novos processos e agregar valor à produção, por meio da intensificação do uso da informação e do conhecimento.

Costa Neto e Canuto (2010) afirmam que a inovação está associada a um processo de geração de novas tecnologias, que se aceleram exponencialmente nos tempos que correm, sucedendo à inovação e aperfeiçoamento de produtos (bens e serviços). Entretanto, a inovação de produto deve ser acompanhada pela inovação tecnológica do processo produtivo, conforme apresentada na Figura 2.4.

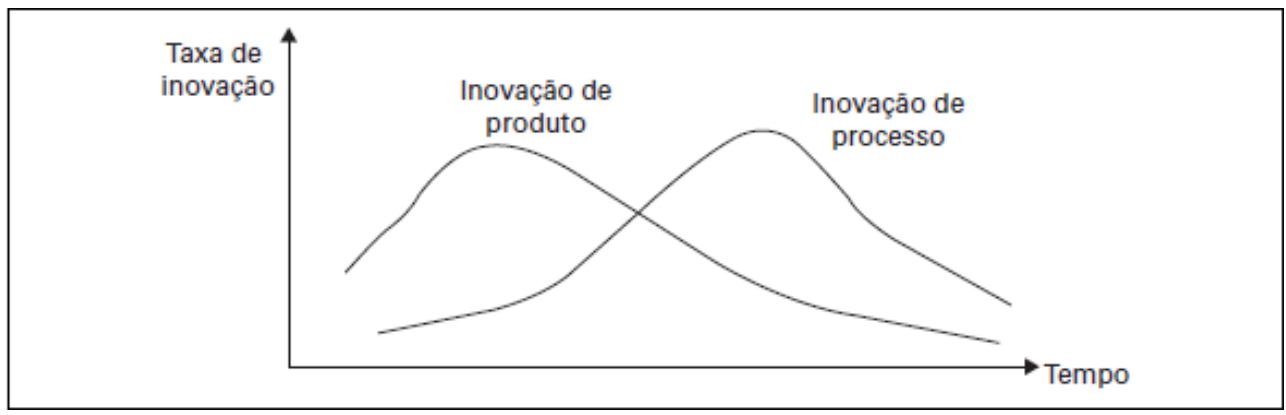

Figura 2.4 - Inovação de Produto e de Processo. Fonte: Costa Neto e Canuto, 2010. 
Os mesmos autores destacam o processo sustentável de inovação tecnológica baseada em tecnologia, demonstrado na Figura 2.5, procurando situar a inovação e os elementos que a cercam, a montante e a jusante de um processo sustentável de realização de novos produtos (bens e serviços) e a agregação de valor econômico. Os elementos presentes nesse conceito são definidos como:

- Pesquisa pura (básica ou fundamental): tem como objetivo aumentar os conhecimentos científicos sem se preocupar com a possibilidade de aplicações práticas.

- Pesquisa aplicada: é a busca de novos conhecimentos científicos ou não, que ofereçam soluções a problemas objetivos, previamente definidos.

- Ciência: é o conjunto organizado dos conhecimentos relativos ao universo objetivo, envolvendo seus fenômenos naturais, ambientais e comportamentais.

- Tecnologia: é o conjunto ordenado de todos os conhecimentos científicos, empíricos ou intuitivos, empregados na produção e comercialização de bens ou serviços.

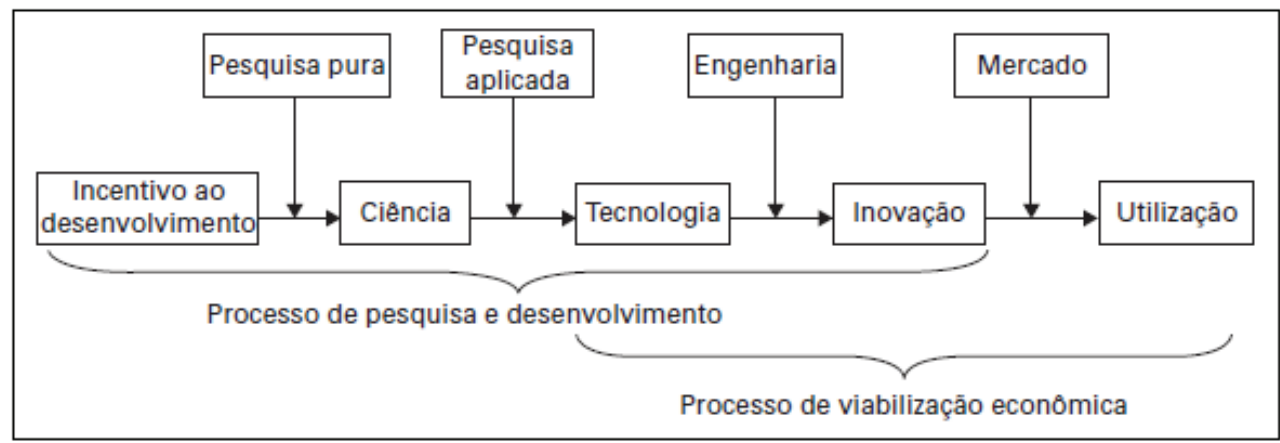

Figura 2.5 - Processo Sustentável de Inovação Tecnológica Baseada em Tecnologia. Fonte: Costa Neto e Canuto, 2010.

Para Freeman e Soete (2008), as atividades de pesquisa e de invenção constituem apenas uma pequena parcela desse complexo mundo das indústrias da informação.

A revolução da pesquisa não foi somente uma questão de mudança de escala, mas envolveu também uma mudança fundamental nas relações entre sociedade e a tecnologia. O próprio uso da palavra tecnologia infere uma mudança nas formas de como se organizam os conhecimentos sobre as técnicas produtivas.

Considerando que para o mundo chegar onde se encontra, houve algumas revoluções como a agrícola e, posteriormente, a industrial, e admitindo que se esteja na revolução tecnológica, modificando o arcabouço do conhecimento e da realidade em que se vive, Toffler (1980) conceitua essas fases em três ondas e ressalta que o analfabeto do século XXI não será aquele que não sabe ler nem escrever, mas aquele que não for capaz de aprender, desaprender e reaprender.

$\mathrm{Na}$ primeira onda (sociedade agrária), a principal forma de capital era a terra, uma forma de criar riqueza cultivando a terra e a necessidade de um mínimo de noção 
sobre o plantio e, ainda, o ânimo corporal para trabalhar, porém, evoluía pouco, por não haver tecnologias em casa, como televisão ou rádio, e as informações provinham das famílias, igrejas e escolas. Nessa onda, a propriedade rural era mantenedora de empregos, caracterizada pelo domínio da agricultura.

$\mathrm{Na}$ segunda onda, a forma de criar riqueza passou a ser a oficina industrial as fábricas. Passaram a serem geradoras de recursos econômicos e financeiros e a fundamental produtora de empregos. O conhecimento provinha dos jornais, revistas, rádio e televisão. As pessoas eram capacitadas para o padrão de produção industrial estabelecido para a época.

$\mathrm{Na}$ terceira onda, o conhecimento adotou o valor do principal recurso econômico e a riqueza construída pela sociedade, que ao agregar a isso o valor aos produtos por elas produzidos, mediante o aproveitamento da inteligência, tem-se o capital-intelectual. A era da informática constitui um moderno estilo de vida, precipitando a absorção de informação e transformando intensamente a estrutura do conhecimento e da realidade em que se vive. O trabalho do homem é substituído pelas inovações tecnológicas, possibilitando o aparecimento da sociedade da informação, a internacionalização do comércio proporcionado pela globalização e um procedimento de universalização da produção e do consumo, administrado pela direção econômica neoliberal, sendo essas as principais características.

Tigre (2006) comenta que os fatores condicionantes da inovação podem ser considerados como:

Oferta: capacitação; conhecimento; capital de risco; gestão; tecnologia e pesquisa e desenvolvimento.

Demanda: qualidade; segurança; customização; conveniência; eficiência; design e meio ambiente.

Ambiente institucional: incentivos fiscais; educação e regulação.

Infraestrutura: transportes; comunicações; informações e redes.

Assim, o modelo de difusão tecnológica pode ser considerado:

Direção: trajetórias tecnológicas dominantes.

Ritmo: velocidade e abrangência da difusão.

Fatores condicionantes: positivos e negativos.

Impactos: emprego e qualificações. Outra questão importante são os fatores condicionantes da difusão tecnológica, que podem ser divididas em:

Técnicos: grau em que uma inovação é percebida como difícil de ser entendida e usada.

Econômicos: custos de aquisição e implantação da nova tecnologia assim como das expectativas de retorno do investimento.

Institucionais: (i) disponibilidade de financiamentos e incentivos fiscais para inovação; (ii) clima favorável ao investimento no país; (iii) acordos internacionais de comércio e investimento; (iv) sistema de propriedade intelectual e (v) existência de capital humano e instituições de apoio. 
Para Plonski (2004), um conceito utilizado na inovação é o open innovation, cunhado em 2003 por Henry Chesbrough, que traz uma reflexão sobre as novas abordagens que buscam trazer maior flexibilidade na geração de inovações tecnológicas. Esse conceito engloba diferentes modelos de colaboração para a inovação em redes de firmas e entidades externas, tais como: clientes, varejistas, fornecedores, concorrentes, universidades e outros laboratórios de pesquisa, e pode variar da simples prestação de serviços (testes de rotina) passando pela aquisição ou transferência de tecnologia até o estabelecimento de alianças estratégicas e consórcios de pesquisa.

Em 2002, o Ministério da Ciência e Tecnologia (C\&T), lançou o Livro branco: ciência, tecnologia e inovação, com o objetivo de propor o debate dos destinos da C\&T nacional, seu papel estratégico para a conformação do futuro do Brasil, as linhas de uma política de longo prazo, no contexto das rápidas e profundas transformações, porque passam o Brasil e o mundo, além das demandas e desafios que a sociedade brasileira terá de enfrentar nesta década.

As diretrizes estratégicas identificadas eram: (1) implantar um efetivo Sistema Nacional de Ciência, Tecnologia e Inovação; (2) promover a inovação para aumentar a competitividade e a inserção internacional das empresas brasileiras; (3) ampliar de forma sustentada os investimentos em Ciência, Tecnologia e Inovação; (4) expandir e modernizar o sistema de formação de pessoal para Ciência, Tecnologia e Inovação; (5) ampliar, diversificar e consolidar a capacidade de pesquisa básica no país; (6) modernizar e consolidar instituições e procedimentos de gestão da política de Ciência, Tecnologia e Inovação e os mecanismos de articulação com as demais políticas públicas; (7) educar para a sociedade do conhecimento; (8) intensificar e explorar novas oportunidades da cooperação internacional em Ciência, Tecnologia e Inovação; e (9) ampliar a dimensão estratégica das atividades de Ciência, Tecnologia e Inovação.

Contudo, na questão de inovação tecnológica, pode-se dizer que o Brasil não a possui de forma geral, uma vez que ainda prioriza a aquisição de máquinas e equipamentos como fonte de inovação, e na maioria das vezes, importados. A compra de tecnologia (máquinas e equipamentos) gera um salto na produção e na produtividade e não conhecimento. Percebe-se que não há interesse dentro do país para adaptar, aperfeiçoar e evoluir a tecnologia que embasa o produto tecnológico adquirido. Aspectos como herança da cultura da substituição de importações, aliada à busca de soluções de curto prazo e menores riscos, levam o país a ser considerado somente um país operário.

Para Vendrametto (2007), o conceito de tecnologia não é de fácil entendimento. A preponderância dos efeitos e consequências provocadas pela tecnologia obscurecem o aspecto mais importante do conceito, que é o conhecimento, constituindo em um verdadeiro divisor de águas entre geradores e os usuários de tecnologia, know-howe know-why. 
O reduzido esforço de Pesquisa, Desenvolvimento e Inovação (P, D \& I) faz com que as empresas nacionais tenham um conhecimento limitado e parcial de seus próprios processos produtivos, uma vez que as empresas estrangeiras trazem os seus conhecimentos da sua matriz, mas não permitem a transferência e conhecimento de tecnologia. O Brasil deve criar maior flexibilidade para adaptação a especificidades locacionais e as tendências da demanda e de investimentos em P, D \& I.

Kim e Nelson (2005) ressaltam que o aprendizado, o espírito empreendedor e a inovação que ocorreram nas chamadas Economias de Industrialização Recente (EIRs), como foi o caso da Coreia do Sul, são extremamente importantes e o entendimento de como conseguiram fazer isso constitui a chave para a percepção das políticas necessárias para as mudanças indispensáveis. Embora o Brasil também faça parte das EIRs, há necessidade dessa mudança de comportamento e com o objetivo, no futuro, de se tornar um país mais desenvolvido e competitivo.

\subsection{Setor de Autopeças}

Segundo Lacerda et al. (2010), a formação dos primeiros focos de produção industrial começou no Brasil só no último quartel do século XIX, especialmente a partir de 1885. No primeiro governo de Getúlio Dornelles Vargas, a indústria brasileira, tardiamente, ganhou um grande impulso, criando leis voltadas para a regulamentação do mercado de trabalho, medidas protecionistas e investimentos em infraestrutura.

Com o final da Segunda Guerra Mundial, a indústria nacional também se beneficiou, uma vez que os países europeus estavam com suas indústrias arrasadas, necessitando importar produtos industrializados de outros países. Embora tivessem períodos de estagnação, principalmente na década de 1980, após o Plano Real, em 1994, a nossa indústria tomou rumos mais sólidos.

Segundo Dosi (2006), dentro das economias capitalistas, o setor empresarial executa atividades inovadoras quando acarretam alguma expectativa de retorno econômico, ou quando a falta de tais atividades acarreta a ameaça de perda de alguns benefícios econômicos vigentes, ou por ambos os motivos. O autor destacou, ainda, que uma das características mais comuns dos estudos de caso industriais é a descrição de diferenças significativas entre firmas, não apenas em termos de tamanho, mas também de capacitações tecnológicas, estratégia de produção e comercialização, graus de inovação, de sucesso competitivo, custos de produção e lucratividade.

É importante que o governo federal desenvolva políticas macroeconômicas com objetivo de fortalecer a política industrial, de tal forma que os segmentos existentes consigam, por meio de um planejamento estratégico, desenvolver ações para diferentes cenários da economia nacional e internacional. 
Ao observar o atual cenário, percebe-se que os países industrializados, de uma forma geral, estão eliminando as fronteiras entre as políticas industriais, de comércio exterior e de tecnologia. Por isso, é importante criar medidas que não sejam simplesmente momentâneas, mas sim sustentáveis.

Conforme Kon (1999), o Brasil só poderá participar e beneficiar-se se as estratégias industriais procurarem se adaptar às novas regras internacionais, estabelecendo projetos de longo prazo que observem a oportunidade de participação conjunta entre países e empresas, e que aumentem os investimentos em pesquisa e em formação de recursos humanos.

Ao abordar o setor de autopeças é importante conceituar que o setor automotivo contempla no aspecto hardware, às montadoras e os fabricantes de autopeças (suprimentos).

No setor de autopeças brasileiro, a dependência de matéria prima pressiona o desempenho e a competitividade, e, assim, faz passar por situações de confronto com sindicatos para manter empregos e salários.

Para Coutinho (1993), historicamente, a indústria de autopeças no Brasil tem se mantido muito verticalizada em decorrência das dificuldades na obtenção de insumo com a qualidade e na quantidade necessárias, assim como em prazo de entrega confiável.

Nesse caso, tanto o setor de autopeças quanto os demais setores da economia buscam estratégias para suprir suas demandas e encontram dificuldades para se manterem no mercado. Com esse foco, a capacidade produtiva se faz importante nesse processo, principalmente no que tange as restrições de capacidade.

A Teoria das Restrições (Theory of Constraints - TOC), idealizada no início dos anos 1970 por Eliyahu Goldratt, contribuiu como alternativa para esses problemas. A base dessa teoria é que qualquer processo é controlado pelo elo mais fraco, restringindo o sistema e limitando a empresa no cumprimento de suas metas.

Para Goldratt e Cox (1993), restrição significa qualquer obstáculo que limita o melhor desempenho do sistema em direção à meta. Assim, parece estar no mercado que não absorve a produção, ou seja, encontra-se dentro da empresa, em alguma política interna. Além disso, define ganho como o índice pelo qual o sistema gera dinheiro por meio das vendas, podendo, inclusive, ser definido como a primeira medida de desempenho do alcance das metas.

A Teoria das Restrições pode ser entendida como uma ampliação do pensamento da Tecnologia da Produção Otimizada (OPT - Optmized Production Technology).

Conforme Slack, Chambers e Johnston (2009), ao identificar a localização da restrição, por meio da OPT, deve-se trabalhar para removê-la e, se for o caso, procurar outra restrição, em que a produção estará sempre focalizando a parte que determina o ritmo da produção. Segundo Davis, Aquilano e Chase (2001), no OPT há uma distinção entre gargalos e recursos restritivos de capacidade (Capacity Constrained Resource-CCR). Um gargalo se aplica ao caso de uma etapa, ou números de etapas, 
de um sistema que não puder processar o bem ou serviço suficientemente rápido para prevenir atrasos (tanto em termos de estoques em processo, como em termos de atendimento da demanda). O CCR é um bem ou serviço necessário para criação do produto final que é esgotado antes que seja entregue.

Slack, Chambers e Johnston (2009) comentam que a capacidade é o nível máximo de atividade de valor agregado e que uma operação, processo ou instalação é capaz de alcançar durante um período de tempo. As restrições de capacidade tornam-se pontos fundamentais na estratégia das empresas.

Para Panizzolo e Garengo (2013), na Teoria das Restrições, um ponto fundamental é ajustar o cronograma entre as operações e os CCR e, assim, garantir que o ponto de controle jamais tenha descompasso.

Alves, Silva e Cogan (2010) comentam que o tamanho de um lote de peças em processo não é igual ao tamanho do lote de transferência, isto é, nem sempre um determinado número de unidades de peças iniciado na produção passa em igual quantidade, no mesmo momento, pelos seus diversos estágios, pois podem ocorrer restrições no sistema. Por isso, qualquer sistema pode apresentar recursos restritivos de capacidade (CCR).

Outro aspecto importante são as recentes aplicações da Teoria das Restrições em Gestão de Operações, que têm adotado o chamado método "Tambor-PulmãoCorda Simplificado" (S-DBR - Simplified Drum-Buffer-Rope) como padrão para planejamento e controle da produção e, ainda, para estabelecer promessas de entregas urgentes mantendo elevada probabilidade de entrega no prazo (SOUZA; BAPTISTA, 2010).

Goldratt (1998) se refere aos recursos restritivos de capacidade (CCR) como o Tambor, porque ele determina o passo ou o ritmo da batida a ser seguido pelo resto dos recursos operacionais. Isso significa que todos os outros recursos produtivos são sincronizados com a programação da restrição.

Basilio et al. (2008) ressaltam que o método Tambor-Pulmão-Corda Simplificado (TPC-S) tem a função de programar a produção em função da restrição do sistema, e o Gerenciamento de Pulmões permite o controle do que foi planejado pelo TPC-S.

Alves, Silva e Cogan (2010) apresentam um exemplo do que seria uma restrição no processo contínuo de operação, constituídos por cinco grupos de trabalho (A, B, C, $\mathrm{D}$ e E), em que cada grupo só consegue produzir certas quantidades de peças por dia.

Cogan (2007) comenta o caso de uma confecção de jeans, em que o início da produção com a matéria prima (tecido jeans) vai passando por cada grupo e cada peça equivale a uma calça parcialmente acabada, sendo identificada a principal restrição no grupo "C", pois ele só é capaz de produzir 5 peças por dia. Como os grupos estão interligados e cada um produz uma parte da calça, se o grupo "C" só consegue produzir 5 peças, então a produção final será de 5 peças, logo, a restrição comanda a produção, conforme demonstrado na Figura 2.6. 


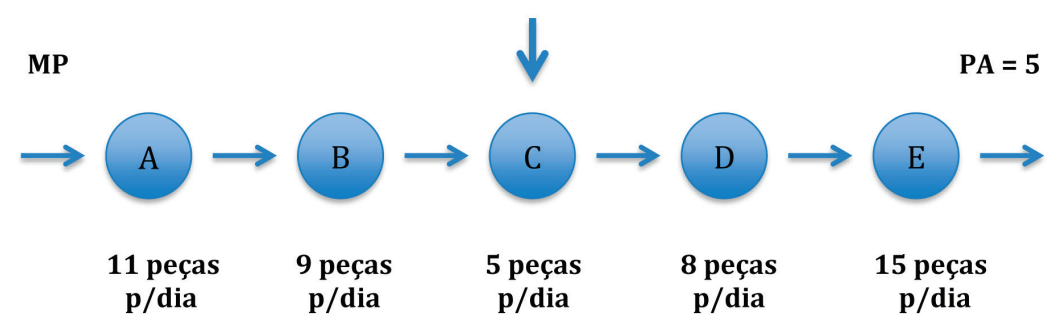

Figura 2.6 - Restrição do Sistema. Fonte: Cogan, 2007.

Alves, Silva e Cogan (2010) explicam o desenvolvimento do método TPC-S, que constitui em: primeiro, desenvolver um cronograma ou plano (Tambor) para saber a data em que o material deve ser adquirido e processado. Quando um grupo acelera ou atrasa demais o ritmo da produção, o tambor é tocado para que diminuam ou aumentem o ritmo. Em segundo lugar, determinar quando deve ser liberado o material para os grupos de trabalho ou a restrição (Corda), servindo para segurar ou puxar, dependendo do ritmo do grupo. Deve ser reservada uma quantidade de material a ser enviada a qualquer momento ao grupo restrição (Pulmão).

Goldratt (1998) ressalta que os gerentes devem administrar adequadamente, ou seja, controlar os custos e proteger o ganho. Deve-se destacar a gestão de produção, pois o gestor deve ter competência para tomar decisões importantes, não perdendo o foco principal da empresa, que é o lucro.

Contador (2008) comenta que competir em custo de produção é diferente de competir em preço do produto. Não obstante as armas serem as mesmas, o objetivo é outro, ou seja, competir em custo é uma arma e não um campo de competição. $\mathrm{Na}$ competição em preço, a empresa visa maior participação de mercado pela autolimitação dos valores cobrados pelos seus produtos. $\mathrm{O}$ autor enfatiza que na competição em custo de produção, a empresa não parte para uma guerra de preços com a concorrência, reduzindo-os, mas objetiva aumentar sua margem operacional pela manutenção de preço paritário com o da concorrência e pela redução de seus custos operacionais.

Contador (2003) relatou que pesquisas mostram que o Brasil possui baixa competitividade internacional. É nítido para todos, e, portanto, não carece de justificativa, que o Brasil, para não ser vencido no ambiente global, precisa adquirir competitividade. Para um país tornar-se competitivo, suas empresas precisam alcançar elevada produtividade. A indústria brasileira, para ser internacionalmente competitiva, precisa dar um salto tão grande em produtividade que dificilmente será acompanhado por equivalente aumento no volume de vendas. Isso implica na inevitabilidade de demissões. Nesse caso, existe outro conflito (trade off), uma vez que ao implantar as inovações tecnológicas, consequentemente, os profissionais devem se qualificar, sob pena de perder o emprego. 
A importância da qualificação de pessoal é assunto indiscutível há muito tempo, tanto na área acadêmica como nas atenções dos empresários e dos gerentes industriais. Entretanto, para muitos desses, essa importância é meramente retórica. (CONTADOR, 2003)

A estratégia de criar uma área para treinar e desenvolver profissionais é uma das alternativas para reduzir esse conflito, apesar de atualmente as empresas buscarem profissionais diferenciados, elas sempre devem ter em mente que o capital humano é o maior responsável para buscar os resultados, ou seja, construir o lucro e mantê-las no mercado, além de contribuir com o desenvolvimento do país.

Segundo Bernstein (1997), pode-se considerar a ideia do capital humano como a soma da educação, do talento natural, do treinamento e da experiência, que constituem a fonte dos futuros fluxos de rendimentos, e assim, é fundamental para a compreensão das grandes mudanças na economia global.

A partir dessa argumentação é importante ressaltar Furtado (1986) na questão do desenvolvimento econômico. Para o autor, o aumento de produtividade econômica no plano da empresa significa, algumas vezes, apenas aumento da taxa de lucros para o empresário, sem repercussão no nível de renda global. Aumento de produtividade é diferente de desenvolvimento, que dificilmente poderia conceber sem elevação da renda real per capita.

$\mathrm{O}$ autor ainda enfatiza que, não obstante, o aumento de produtividade física no plano da empresa, pelo fato de que se baseia, quase sempre, na incorporação de novas técnicas e, ainda, contribui para liberar mão de obra, é fenômeno de grande importância no processo de desenvolvimento.

As empresas devem desenvolver planos estratégicos para melhorias dos seus processos e operações, considerando que o maior objetivo de toda empresa é criar uma gestão de produção eficaz e adequada e gerar ganho (lucro), que corresponde a Receita Total menos Custo Total. Para Bruni e Famá (2009), ganho ou throughput corresponde à geração de recursos monetários por meio das vendas dos seus produtos ou serviços.

O setor automotivo brasileiro está entre os mais importantes do país e tanto os setores automobilísticos (montadoras) e autopeças (suprimentos) desempenham funções importantes. No caso das autopeças, na distribuição geográfica das plantas industriais, o estado de São Paulo está em primeiro lugar, com uma quantidade muito superior em relação ao segundo lugar, o estado de Minas Gerais, 472 e 76, respectivamente, como se observa na Figura 2.7. 


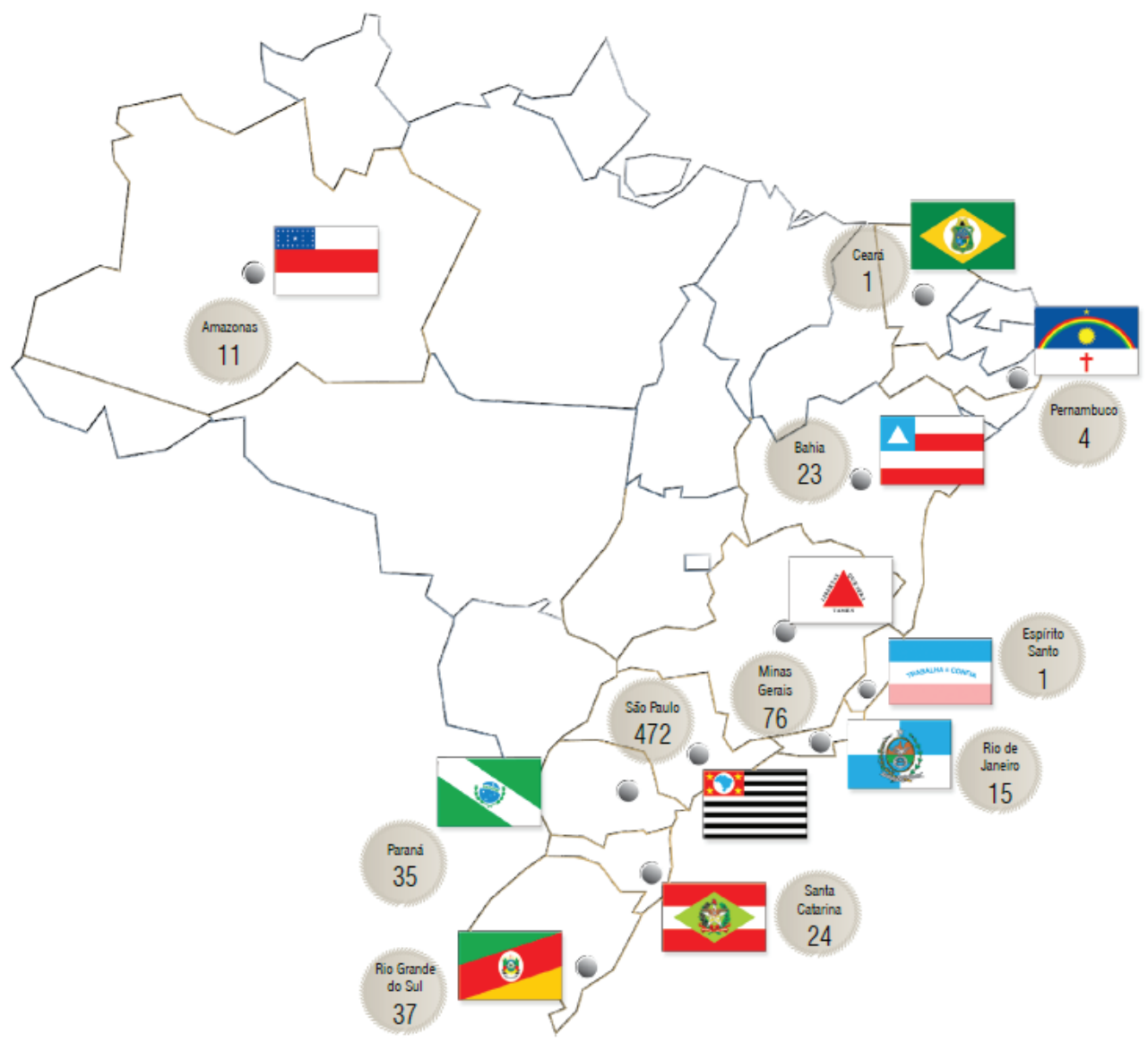

Figura 2.7 - Distribuição Geográfica das Plantas Industriais das Autopeças Brasileiras. Fonte: Sindipeças, 2013.

Conforme o Relatório de Desempenho do Setor de Autopeças de 2013, os principais indicadores da indústria brasileira de autopeças indicam a dimensão desse setor industrial, elo fundamental da cadeia de produção automotiva. Em 2012, os cerca de quinhentos associados do Sindipeças e da Abipeças registraram faturamento de US\$ 41,8 bilhões, em valores deflacionados e convertidos pela taxa média do câmbio. As vendas para montadoras, principal segmento de mercado, representaram $69,3 \%$ do total faturado; a reposição, $14,7 \%$; as exportações, $8,6 \%$; e as vendas intrassetoriais, 7,4\%. Nesse ano, o setor empregou 218,4 mil trabalhadores e investiu aproximadamente US\$ 1,9 bilhão, 4,5\% do faturamento (SINDIPEÇAS, 2013).

Conforme relatórios econômicos sobre o Desempenho da Indústria de Autopeças Brasileira (SINDIPEÇAS, 2013), podem-se observar os resultados de 2009 a 2012 e as projeções para 2013 e 2014. 
Referente ao Faturamento Nominal, percebe-se que entre 2013/2012 houve leve melhora na variação percentual do faturamento nominal (Tabela 2.1) em reais ( $\mathrm{R}$ \$ bilhões) e na variação percentual em dólares (US\$ bilhões), porém, ainda baixo e com uma projeção otimista para 2014, mas não satisfatória. Além disso, no mesmo relatório do Sindipeças comenta que o setor aguarda a expectativa de crescimento do Produto Interno Bruto (PIB) do país, e ainda, enfrentar alguns desafios como a concorrência com produtos importados dos Estados Unidos e de países asiáticos.

Tabela 2.1 - Faturamento Nominal. Fonte: Sindipeças, 2013.

\begin{tabular}{|c|c|c|c|c|c|c|c|c|c|c|c|c|}
\hline \multicolumn{13}{|c|}{ FATURAMENTO NOMINAL W } \\
\hline ano fiscal & \multicolumn{2}{|c|}{2009} & \multicolumn{2}{|c|}{2010} & \multicolumn{2}{|c|}{2011} & \multicolumn{2}{|c|}{2012} & \multicolumn{2}{|c|}{$\begin{array}{c}2013 \\
\text { (projeçāo) }\end{array}$} & \multicolumn{2}{|c|}{$\begin{array}{c}2014 \\
\text { (projeçōo) }\end{array}$} \\
\hline $\begin{array}{l}\text { unidade } \\
\text { monetárias }\end{array}$ & $\begin{array}{c}\text { valor } \\
\text { monetário }\end{array}$ & $\begin{array}{l}\text { varioģà \$ } \\
2009 / 2008\end{array}$ & $\begin{array}{c}\text { valor } \\
\text { monetário }\end{array}$ & $\begin{array}{l}\text { variaçào \$ } \\
2010 / 2009\end{array}$ & $\begin{array}{c}\text { valor } \\
\text { monetário }\end{array}$ & $\begin{array}{l}\text { variaç̧ōo \% } \\
2 \quad 1 / 2010\end{array}$ & $\begin{array}{c}\text { valor } \\
\text { monetário }\end{array}$ & $\begin{array}{l}\text { varisş̧òo \$ } \\
2012 / 2011\end{array}$ & $\begin{array}{c}\text { valor } \\
\text { monetário }\end{array}$ & $\begin{array}{l}\text { varioģào \$ } \\
2013 / 2012\end{array}$ & $\begin{array}{c}\text { valor } \\
\text { monetário }\end{array}$ & $\begin{array}{l}\text { variação \% } \\
\text { 2014/2013 }\end{array}$ \\
\hline RS bilhōes & 75,67 & $0,7 \%$ & 86,39 & $14,2 \%$ & 91,26 & $5,6 \%$ & 81,72 & $-10,5 \%$ & 83,92 & $2,7 \%$ & 87,72 & $4,5 \%$ \\
\hline USS bilhōes & 37,90 & $-7,6 \%$ & 49,77 & $31,3 \%$ & 54,51 & $9,5 \%$ & 41,82 & $-23,3 \%$ & 41,96 & $0,3 \%$ & 42,58 & $1,5 \%$ \\
\hline
\end{tabular}

A participação porcentual do faturamento por segmento (Tabela 2.2) é nítida, a prevalência do segmento das montadoras, de forma quase que absoluta, ao atingir $70 \%$ do mercado.

Tabela 2.2 - Participaç̣̃o Porcentual do Faturamento por Segmento. Fonte: Sindipeças, 2013.

\begin{tabular}{|c|c|c|c|c|c|c|}
\hline \multicolumn{7}{|c|}{$\begin{array}{l}\text { PARTICIPAÇO PORCENTUAL DO FATURAMENTO POR SEGMENTO } \\
\qquad(\mathrm{em} \mathrm{s})\end{array}$} \\
\hline segmento & 2009 & 2010 & 2011 & 2012 & $\begin{array}{c}2013 \\
\text { (projeç̧o) }\end{array}$ & $\begin{array}{c}2014 \\
\text { (projegajo) }\end{array}$ \\
\hline Montodore & 68,8 & 70,5 & 70,8 & 69,3 & 70,2 & 70,3 \\
\hline Reposiçào & 14,3 & 14,6 & 14,7 & 14,7 & 14,8 & 14,9 \\
\hline Exportayào & 9,3 & 7,5 & 8.4 & 8,6 & 7,9 & 7,8 \\
\hline Intrassetorial & 7,6 & 7,3 & 6,1 & 7,4 & 7,1 & 7,0 \\
\hline
\end{tabular}

Nos investimentos totais (Tabela 2.3), observa-se uma gradativa redução a partir de 2012, com projeções para 2014 mais pessimistas.

Tabela 2.3 - Investimentos Totais. Fonte: Sindipeças, 2013.

\begin{tabular}{|r|c|c|c|c|c|c|}
\hline \multicolumn{9}{|c|}{ INVESTIMENTOS TOTAIS } \\
\hline ono fiscal & 2009 & 2010 & 2011 & $2012 \quad \begin{array}{c}2013 \\
\text { (projeçäo) }\end{array}$ & $\begin{array}{c}2014 \\
\text { (projeräa) }\end{array}$ \\
\hline $\begin{array}{r}\text { Investimentos } \\
\text { em US5 bilhöes }\end{array}$ & 0,631 & 2,156 & 2,418 & 1,891 & 1,439 \\
\hline
\end{tabular}


Em relação aos resultados (2009 a 2012) e projeções (2013 e 2014) da balança comercial (Tabela 2.4), observa-se que os resultados são de déficits, ou seja, as importações continuam sobressaindo sobre a produção de peças dentro do país e, evidentemente, uma tendência negativa é que as montadoras podem importar mais peças, de forma a desestimular o setor de autopeças nacional.

\section{Tabela 2.4 - Balança Comercial. Fonte: Sindipeças, 2013.}

\begin{tabular}{|c|c|c|c|c|c|c|c|c|c|c|c|c|}
\hline \multicolumn{13}{|c|}{ BALANCAA COMERCIAL } \\
\hline \multirow{2}{*}{$\begin{array}{l}\text { sno fiscal } \\
\text { em USS billhōes } 508\end{array}$} & \multicolumn{2}{|c|}{2009} & \multicolumn{2}{|c|}{2010} & \multicolumn{2}{|c|}{2011} & \multicolumn{2}{|c|}{2012} & \multicolumn{2}{|c|}{$\begin{array}{c}2013 \\
\text { (projeção) }\end{array}$} & \multicolumn{2}{|c|}{$\begin{array}{c}2014 \\
\text { (projeçầ) }\end{array}$} \\
\hline & $\begin{array}{c}\text { valor } \\
\text { monetário }\end{array}$ & $\begin{array}{l}\text { varioşåo \% } \\
\text { 2009/2003 }\end{array}$ & $\begin{array}{c}\text { valor } \\
\text { monetário }\end{array}$ & $\begin{array}{l}\text { voriaşão \$ } \\
2010 / 2009\end{array}$ & $\begin{array}{c}\text { valor } \\
\text { monetário }\end{array}$ & $\begin{array}{l}\text { variaç̧o \% } \\
\text { 2011/2010 }\end{array}$ & $\begin{array}{c}\text { valor } \\
\text { monetário }\end{array}$ & $\begin{array}{l}\text { variaşào \% } \\
2012 / 2011\end{array}$ & $\begin{array}{c}\text { valor } \\
\text { monetário }\end{array}$ & $\begin{array}{l}\text { varieçào \% } \\
2013 / 2012\end{array}$ & $\begin{array}{c}\text { valor } \\
\text { monetário }\end{array}$ & $\begin{array}{l}\text { variação \$ } \\
\text { 2014/2013 }\end{array}$ \\
\hline Exportasão & 6,74 & & 9,60 & $42,5 \%$ & 11,13 & $15,9 \%$ & 10,47 & $-5,9 \%$ & 10,56 & $0,9 \%$ & 10,60 & $0,3 \%$ \\
\hline Importação & 9,12 & & 13,15 & $44,1 \%$ & 15,78 & $20,0 \%$ & 16,26 & $3,1 \%$ & 17,02 & $4,7 \%$ & 18,18 & $6,8 \%$ \\
\hline $\begin{array}{r}\text { Resultado } \\
(-) \text { déficit ou } \\
(+) \text { superínit }\end{array}$ & $(2,38)$ & & $(3,55)$ & & $(4,64)$ & & $(5,79)$ & & $(6,46)$ & & $(7,58)$ & \\
\hline
\end{tabular}

$\mathrm{Na}$ Tabela 2.5, referente ao mercado de trabalho, percebe-se a redução do número de postos de trabalho de 2009 a 2012 e, embora ainda apresente uma variação percentual entre 2013/2012 (projeção), é positiva em apenas 0,5\% e uma projeção positiva para 2014 de apenas 1,6\%, sendo resultados pífios e decepcionantes.

Tabela 2.5 - Mercado de Trabalho - Número de Postos de Trabahho. Fonte: Sindipeças, 2013.

\begin{tabular}{|c|c|c|c|c|c|c|c|c|c|c|c|c|}
\hline \multicolumn{13}{|c|}{ MERCADO DE TRABALHO - NÚMERO DE POSTOS DE TRABALHO } \\
\hline sno fiscal & \multicolumn{2}{|c|}{2009} & \multicolumn{2}{|c|}{2010} & \multicolumn{2}{|c|}{2011} & \multicolumn{2}{|c|}{2012} & \multicolumn{2}{|c|}{$\begin{array}{c}2013 \\
\text { (projeçào) }\end{array}$} & \multicolumn{2}{|c|}{$\begin{array}{c}2014 \\
\text { (projeçīo) }\end{array}$} \\
\hline indicador variáveis & $\mathrm{dez} / 09$ & $\begin{array}{l}\text { variação \% } \\
2009 / 2008\end{array}$ & dez/10 & $\begin{array}{l}\text { veriação \% } \\
2010 / 2009\end{array}$ & $\mathrm{dez} / 11$ & $\begin{array}{l}\text { verisç̧̇o\% } \\
\text { 2011/2010 }\end{array}$ & dez/12 & $\begin{array}{l}\text { varieção \% } \\
2012 / 2011\end{array}$ & dez/13 & $\begin{array}{l}\text { variaçào \% } \\
\text { 2013/2012 }\end{array}$ & dez/14 & $\begin{array}{l}\text { varisção \% } \\
2014 / 2013\end{array}$ \\
\hline $\begin{array}{r}\text { Número de empregados } \\
\qquad \text { [em milhares] }\end{array}$ & 199,5 & $-3,9 \%$ & 224,6 & $12,6 \%$ & 229,5 & $2,2 \%$ & 218,4 & $-4,8 \%$ & 219,5 & $0,5 \%$ & 223,0 & $1,6 \%$ \\
\hline
\end{tabular}

O governo federal criou em 2012 o Inovar-Auto, programa de incentivo à inovação tecnológica e adensamento da cadeia produtiva de veículos automotores, com o objetivo de estimular o investimento na indústria automobilística nacional, com previsão de aporte de mais de R \$ 50 bilhões até 2015 (INOVAR-AUTO, 2013).

Somente a partir de maio de 2013, o governo federal incentivou o setor automotivo com a redução do Imposto sobre Produtos Industrializados (IPI) para as categorias mais populares e, no primeiro semestre, os resultados também foram afetados pelo câmbio, que favoreceu as importações. Em fevereiro, a cotação do dólar era de R \$ 2,06, caindo para $\mathrm{R} \$ 1,97$ em março e se mantendo nesse patamar até junho de 2013, quando chegou a R \$2,12. Somente em agosto acelerou para $\mathrm{R}$ \$2,24, chegando a $\mathrm{R} \$$ 2,40 em setembro (SINDIPEÇAS, 2013).

Enfim, nesse cenário apresentado, percebe-se a necessidade de medidas mais concretas e objetivas para melhorar o desempenho desse setor. 


\subsection{Business Intelligence (BI)}

O termo BI (Business Intelligence) em português, significa Inteligência de Negócio. O seu conceito surgiu na década de 1980 cunhada pela GartnerGroup e se refere ao processo de coleta, organização, análise, compartilhamento e monitoramento de informações que oferecem suporte a gestão de negócios (PRIMAK, 2008).

Para Amaral (2011), o BI descreve o termo como uma habilidade que as corporações possuem ao explorar dados e informações que estão contidos em um Data Warehouse (DW) / Data Marts (DM), e, por meio de ferramentas específicas, podem ser analisadas e desenvolvidas percepções e entendimentos, permitindo com isso, obter informações fundamentadas e mais confiáveis para a tomada de decisão. Dessa forma, antes de discorrer sobre o conceito de BI, é importante conceituar DW e DM.

Para Inmon (2005), DW é uma coleção de dados orientados por assuntos, integrados, variáveis com o tempo e não voláteis, para dar suporte ao processo de tomada de decisão e, para Kimball (2002), DW pode ser definido como um conjunto de todos os DM's da organização, em que a informação é sempre armazenada em um modelo dimensional. Os DM's são subconjuntos de um DW completo. Conforme Amaral (2011), pode-se visualizar DM's como pequenos DW's, sejam eles de visão departamental ou de área interesse.

O DW é um dos conceitos básicos que está contido nas estratégias do BI, pois permite aproveitar a vantagem de ter criado uma base de conhecimento ao longo do tempo. Entretanto, para que essas informações sejam facilmente perceptíveis na solução, é importante que a inserção de dados no sistema seja correta e verídica, caso contrário, a decisão pode ser prejudicada.

Para Machado (2010), o DW une bancos de dados de toda uma empresa. Um DM, normalmente é menor e se concentra em um assunto ou departamento específico, sendo considerado um subconjunto do DW. O DM pode ser montado por simples filtros lógicos, ou mesmo pela replicação dos dados do DW, entre outros servidores.

Conforme Amaral (2011), em uma visão comparativa dos dados, em que consideramos como quesitos, o escopo, integração, tempo, agregação, análise e dados voláteis, nota-se que a diferença está no escopo, pois enquanto o DW é feito para atender uma empresa como um todo, o DM é criado apenas para atender um departamento da empresa.

As principais características do DW, conforme Inmon (2005), são:

Orientado por assuntos: a modelagem é desenvolvida especificamente sobre os principais assuntos da empresa, que são informações relativas à determinada área estratégica de uma empresa;

Integrado: é possível padronizar uma representação única para os dados de todos os sistemas que formarão a base de dados do DW;

Não são voláteis: as informações ao serem carregadas na base analítica do DW 
se tornam uma carga não volátil, o que significa que a partir daquele momento as informações não serão alteradas, somente consultadas, conforme apresentada na Figura 2.8.

Variante no tempo: um sistema de apoio à decisão deverá possuir um histórico de operações ocorridas a imediato, curto e longo prazos, podendo chegar a 10 anos, mesmo com esse período estendido, os custos com arquivamento dos dados não é tão alto, o custo mais significativo é com a transmissão dos dados das bases operacionais para analítica no DW.

Operacional

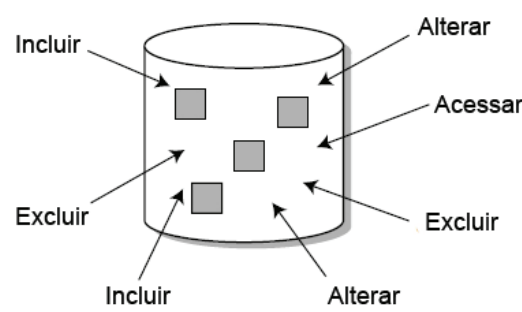

Data Warehouse

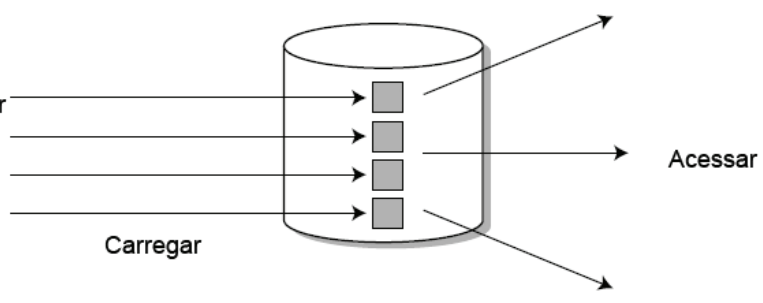

Figura 2.8 - Data Warehouse: Não Volatilidade. Fonte: Inmon, 2005.

A modelagem dimensional, conforme Kimball (2002), é uma técnica de projeto lógico, que busca apresentar os dados em uma estrutura padronizada mais intuitiva, além de permitir alto desempenho de acesso, evitando a utilização da técnica de normalização. Essa técnica de modelagem é especificamente utilizada para suportar processamento analítico OLAP (OnLine Analytical Processing).

Conforme Amaral (2011), essa modelagem apresenta uma natural e grande extensibilidade para acomodar novos e inesperados elementos de dados, e novas decisões de projeto. O conceito de grande extensibilidade é a capacidade de todas as tabelas existentes poderem ser modificadas localmente pela simples adição de novas linhas de dados na tabela. As ferramentas de consulta e geradoras de relatórios não necessitam serem reprogramadas para acomodar as modificações e todas as aplicações continuam a rodar sem proporcionar diferentes resultados.

O conceito de OLAP, segundo Jacobson e Misner (2007), é um conjunto de ferramentas e técnicas que permite realizar a exploração dos dados de um DW, utilizando os recursos de modelagem, análise e visualização de grandes conjuntos de dados e ainda, contribui na análise de forma mais eficiente na quantidade de dados crescentes armazenados pelas organizações, transformando-os em informação.

Em modelos multidimensionais, conforme Amaral (2011), os dados podem estar organizados em múltiplas dimensões. Em cada dimensão pode haver múltiplos níveis de abstração que podem estar estruturados por um conceito de hierarquia. 
Essa organização provê condições para a realização de operações OLAP (drilldown, roll-up, pivot, sliceanddice), permitindo a geração de consultas ad-hoc, ou seja, consultas personalizadas. O usuário possuirá uma flexibilidade para observar os dados a partir de diferentes perspectivas e em diferentes níveis de detalhe.

Graficamente, modelos multidimensionais podem ser representados por meio de um cubo de dados. Conforme Amaral (2011), as operações sobre esse cubo propiciam a materialização de diferentes perspectivas de visualização, oferecendo suporte à realização de consultas e análises interativas sobre os dados armazenados. A seguir, são detalhados os tipos das operações OLAP, baseado no mesmo autor.

A operação de drill-down ocorre quando o usuário deseja aumentar o nível de detalhe da informação, diminuindo o nível de granularidade. Nesse caso, o resultado da operação de drill-down é aplicada sobre o cubo central, descendo sobre a hierarquia de tempo (day<month<quarter<year). Mostra que a operação desce do nível de semestre (quarter) para mês (month).

A operação roll-up ou drill-up, aplica uma agregação sobre o cubo de dados, o qual aumenta o nível de granularidade dentro de uma dimensão, reduzindo o detalhamento da informação. Nesse caso, o resultado da operação de roll-up é aplicada no cubo central, subindo na hierarquia de location. Essa hierarquia é definida de acordo com a seguinte ordem: street<city<province_or_state<country. Essa agregação mostra uma ascensão na hierarquia de location, do nível de city para o nível de country.

O operador pivot realiza uma operação de visualização que rotaciona os eixos de um determinado cubo, concedendo uma visão alternativa sobre o cubo de dados. Nesse caso, na operação de pivot sobre o resultado de uma operação de slice, pode-se observar uma rotação em duas dimensões e, também, o mesmo pode ser feito, em um cubo 3D.

A operação de slice executa uma seleção sobre uma das dimensões de um determinado cubo, resultando em um subcubo. Nesse caso, é possível visualizar um exemplo da operação de slice, que seleciona as vendas por cidade em um determinado semestre (quarter $=\mathrm{Q} 1)$.

$\mathrm{Na}$ operação de dice, também, tem-se um subcubo, porém, por meio de uma seleção sobre duas ou mais dimensões. Nesse caso, tem-se uma operação de dice envolvendo três dimensões, com base nos seguintes critérios (location = "Toronto" ou "Vancouver" || time = "Q1" ou "Q2" || item = "home entertainment" ou "computer").

Essas operações típicas de dados multidimensionais são exemplificadas na Figura 2.9 sobre o cubo central. 


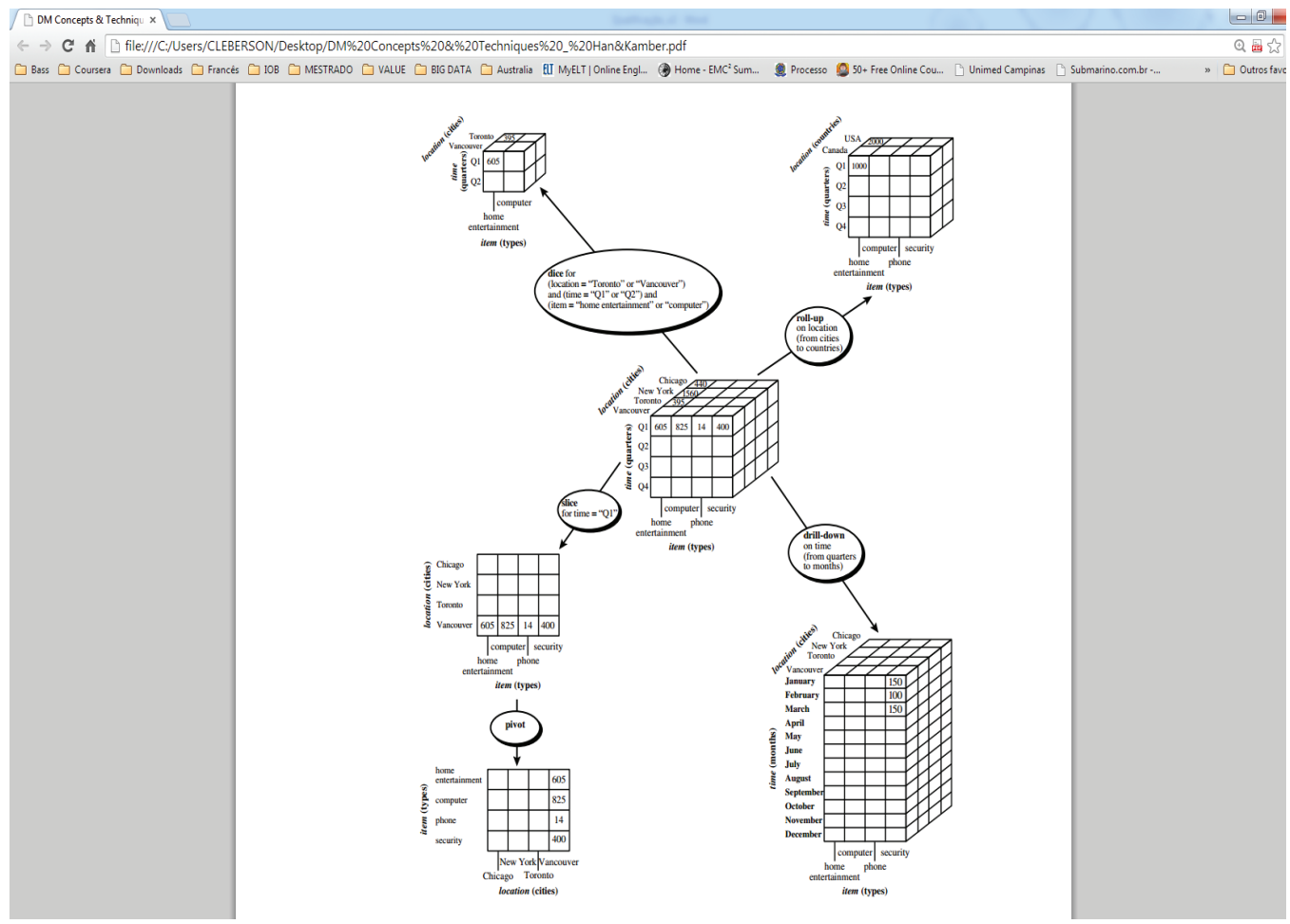

Figura 2.9 - Exemplos de Operações OLAP Típicas de Dados Multidimensionais. Fonte: Amaral, 2011.

O esquema estrela, do banco de dados, consiste em uma grande entidade central denominada fato (facttable) e um conjunto de entidades menores, denominadas dimensões (dimensiontables). A tabela fato fica localizada no centro do modelo, e suas tabelas de dimensões ficam arranjadas ao redor dessa unidade central, originando um formato semelhante ao de uma estrela (MACHADO, 2010).

Amaral (2011) comenta que, nesse modelo, todas as tabelas dimensões relacionamse por meio dos atributos chaves primárias ( $P K$ - Primary Key), diretamente com a tabela fato, localizada no centro da figura, que contém a chave primária PK, composta por chaves estrangeiras de relacionamento (FK - Foreign Key) com as tabelas dimensões. A tabela fato contém os valores numéricos ou medidas dos fatos consultados.

Para ilustrar esse conceito, o modelo dimensional clássico de Inmon (2005) é apresentado na Figura 2.10. 


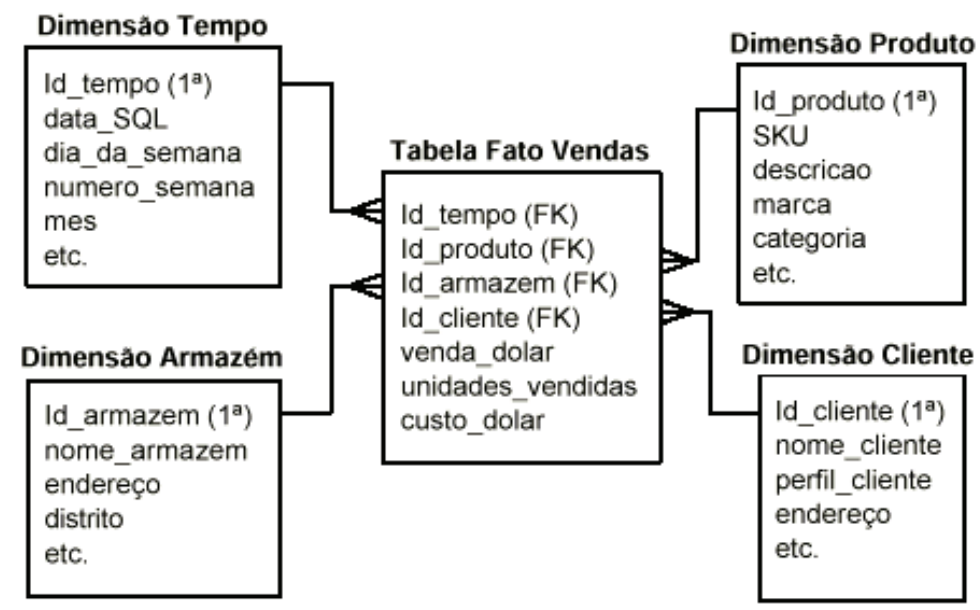

Figura 2.10 - Esquema Estrela do Banco de Dados. Fonte: Inmon, 2005.

A utilização de um modelo dimensional do tipo estrela para os processos de consultas, pode trazer benefícios significativos em relação a uma estrutura relacional. Podem-se destacar, de acordo com Amaral (2011), os seguintes benefícios: Reduzir o tempo de resposta nas consultas complexas;

- Adequar os dados para as reais necessidades do tomador de decisão;

- Simplificar o entendimento e navegação entre os dados;

- Adaptar a um número maior de ferramentas OLAP;

- Amenizar os impactos de novas implementações;

- Maior flexibilidade na implementação de novas dimensões;

- Menor tempo nos processos de ETL (Extract, Transform, Load).

Outro modelo importante e mais complexo que o esquema estrela é o apresentado por Kimball (2002), denominado de esquema snowflake (flocos de neve). Nesse modelo é possível normalizar dimensões com o propósito de eliminar redundâncias, que por outro lado irá resultar em consultas mais complexas e com redução de desempenho. Os dados dimensionais são agrupados utilizando-se múltiplas tabelas, ao invés de uma única. Na Figura 2.11 é apresentada o esquema snowflake (flocos de neve). 


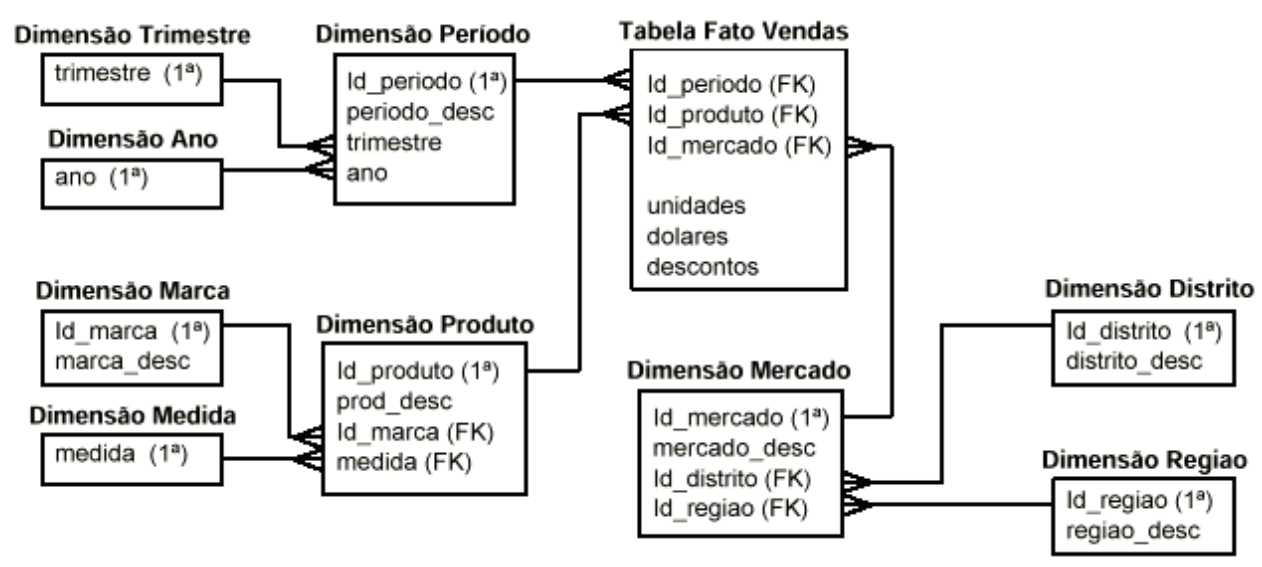

Figura 2.11 - Esquema Snowflake (Flocos de Neve). Fonte: Inmon, 2005.

Outro conceito importante é a granularidade, destacada por Inmon (2005) como aquela que corresponde ao nível de detalhe ou do resumo em que os dados serão sumarizados nas unidades de dados do DW.

Segundo Almeida (2009), quanto menor a granularidade, maior o nível de detalhes e, consequentemente, maior o volume de dados armazenado. Quantidades maiores de detalhes tendem a afetar o desempenho das consultas ao banco, deixando o tempo de resposta da consulta mais longo.

O processo de ETL (Extract, Transform, Load), que em português significa Extração, Transformação e Carga de Dados, é composto por três tarefas, das quais, por muitas vezes tornam-se as mais trabalhosas para o administrador de DW, que deve dar maior dedicação e cuidado. Conceituando cada uma das etapas:

Extração: responsável pela aquisição dos dados de origem. Na maior parte das vezes, essa origem é heterogênea e são definidas como registros que existem em muitos formatos e localizações diferentes.

Transformação: determina a padronização dos dados. Nessa etapa, ocorrem a validação da integridade dos dados e a sua transformação. É também nessa fase que é feita a padronização dos campos e valores obrigatórios para o destino.

Carga: a última etapa e a mais delicada para o processamento, pois é nessa etapa que os dados são efetivados no destino.

Hoje, os modernos sistemas de BI incluem importantes recursos de inteligência artificial e de análise, abrindo um horizonte de possibilidades para pequenas, médias e grandes empresas, por meio da utilização de dados históricos dos sistemas transacionais e dos sistemas legados, no apoio a tomada de decisão, desde o nível estratégico até o operacional (TURBAN et. al. 2009).

Souza, Ribeiro e Isoton (2009) comentam que o BI pode ser utilizado nas três camadas da pirâmide organizacional. $\mathrm{Na}$ camada operacional podem-se analisar e 
auditar dados e detalhes dos clientes. Na tática, podem-se simular melhores condições de compra e de venda. Na estratégica, é possível controlar metas e os objetivos das empresas.

O BI é uma tecnologia capaz de possibilitar às empresas organizarem grandes quantidades de seus dados, de forma ágil, cruzando as informações para permitir uma tomada de decisões mais acertada e fácil, principalmente nas atividades empresariais, conforme apresentado na Figura 2.12.

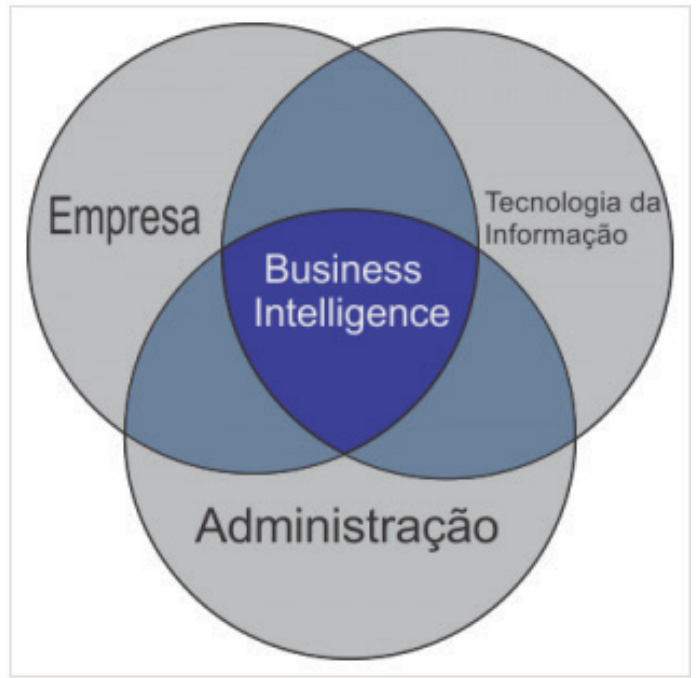

\section{Figura 2.12 - Princípio do BI. Fonte: Consultoria SAP Business Intelligence, 2013.}

O BI pode também ser utilizado para atingir muitas metas, tais como novas oportunidades de negócios, contribuir em uma visão mais profunda do consumidor, aumentar o faturamento, reduzir os custos, ajustar os orçamentos, além de contribuir para substituir relatórios e procedimentos de relatos estáticos por dinâmicos e em tempo real, garantindo que as ações sejam realizadas a qualquer momento (ABELLÓN, 2007).

O processo de BI baseia-se na transformação de dados em informações. O principal benefício do BI para uma organização é a capacidade de fornecer informações precisas quando necessário, incluindo uma visão em tempo real do desempenho corporativo. Essas informações são necessárias para todos os tipos de decisões, principalmente para o planejamento estratégico (TURBAN et. al., 2009).

A Figura 2.13 demonstra que para ter esse tipo de maturidade é necessário tempo e investimento, mas as vantagens obtidas após atingir um nível alto de maturidade são muitas. 


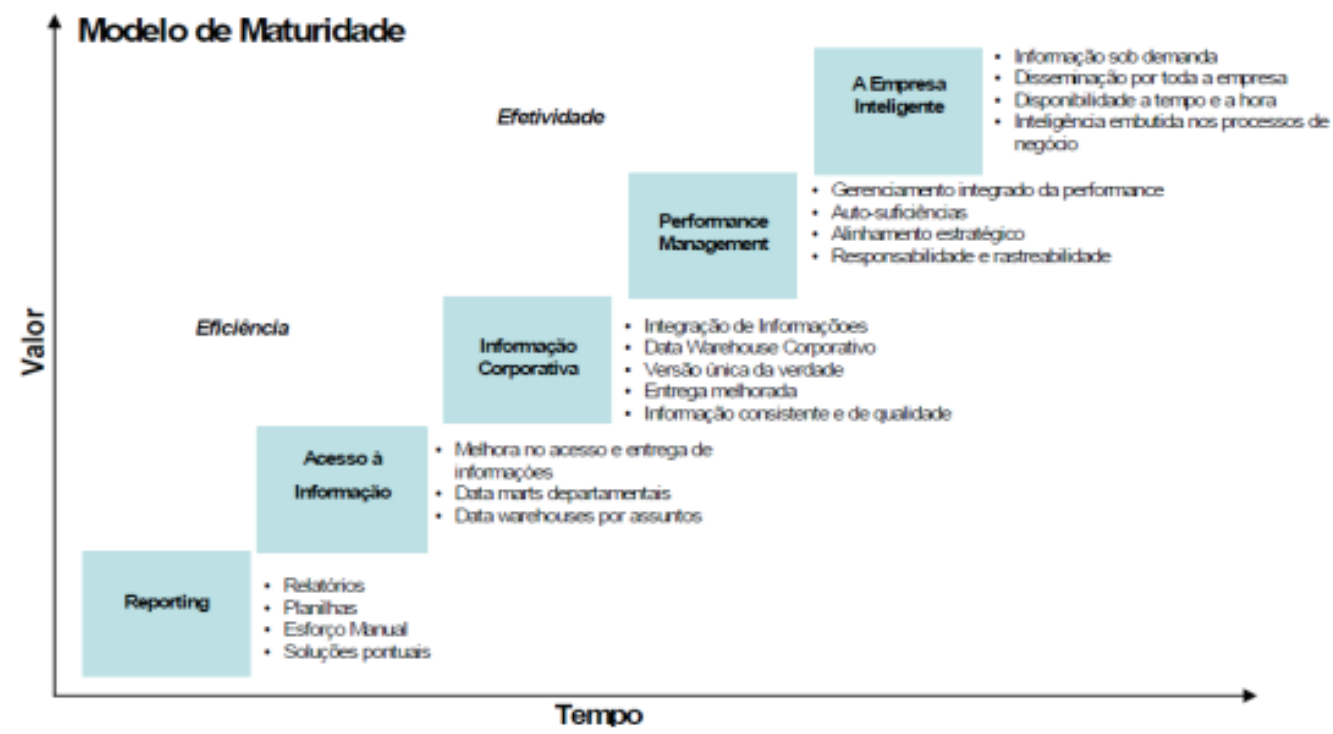

Figura 2.13 - Evolução da Maturidade do BI no Negócio. Fonte: IBM, 2008.

Para Romero e Sassi (2011), a arquitetura BI pode contribuir muito para obtenção de informações e na correlação de dados externos e internos da companhia, porém, necessita que os processos e sistemas estejam mapeados e organizados, para dessa forma otimizar ao máximo a sua utilização.

Atualmente, o BI também está sendo utilizado no setor público, auxiliando no acompanhamento e tomada de decisões pelos seus governantes, e, ainda, apresentando maior transparência da administração pública, permitindo avaliar melhor, de forma quali-quantitativo, o desempenho organizacional.

Para Leite e Rezende (2010), os desafios são constantes para a gestão pública e se torna imprescindível a estruturação e disponibilização das informações confiáveis, oportunas e personalizadas para apoiar as decisões da administração pública municipal e, com isso, um planejamento por meio de modelos de gestão da iniciativa privada para setor público, sendo esta uma alternativa.

Conforme Sant'ana e Rodrigues (2013), ambientes para acesso a dados governamentais, via Tecnologias de Informação e Comunicação (TIC), podem ampliar possibilidades de acompanhamento pelo cidadão, retroalimentando futuras demandas.

Dentre os principais benefícios que uma solução de BI traz para as organizações, destacam-se, conforme Silva (2013):

- Reduzir os processos e agilizar, flexibilizar e personalizar as informações e seus relatórios;

- Substituir outras ferramentas, como por exemplo, Excel, no sentido de desenvolver fórmulas no mesmo para busca de informações, e de outros sistemas mais "engessados", em termos de gerar informações e relatórios; 
- Facilitar as modificações e/ou melhorias nos relatórios, como por exemplo, alterar a forma de apresentar os dados e acrescentar novas informações, contribuindo para a evolução contínua das análises de informações, como também da tecnologia, e ainda, disponibilizar vários relatórios para confrontar os dados entre os diversos módulos do próprio BI;

- Disponibilizar as informações na tela do software em poucos segundos, dependendo dos filtros (parâmetros) realizados;

- Facilitar o planejamento da empresa nos três níveis: estratégico, tático e operacional;

- Acessar as informações praticamente online.

Pode-se perceber a importância da utilização de ferramentas da área de Tecnologia de Informação que ofereçam apoio e possam transformar as informações relevantes em decisões importantes para o futuro das empresas e, evidentemente, para o país se desenvolver. Nesse caso, o Business Intelligence (BI) está nesse patamar, e o LOGEST da Microsoft, no nível para projetar as tendências e vislumbrar ações para o futuro.

\subsection{Panorama Econômico: Brasil; Alemanha; Estados Unidos; Coreia do Sul; India; Rússia; China e África do Sul}

Baseado no Relatório de Competitividade Global da WEF (2013-2014), é apresentado um breve panorama econômico e comentários da WEF sobre os países escolhidos para análise desta tese. Os países escolhidos são: Brasil; Alemanha; Estados Unidos; Coreia do Sul; Índia; Rússia; China; e África do Sul.

\subsection{BRASIL}

Considerado um país emergente e a maior economia da América Latina, o Brasil possui uma extensão territorial de $8.514 .876 \mathrm{~km}^{2}$, ocupa o sétimo lugar no ranking das maiores economias do mundo e o $56^{\circ}$ lugar no Relatório de Competitividade Global (WEF 2013-2014). Tem uma economia, pós Plano Real, mais estável, aberta e inserida no processo de globalização. É um grande produtor e exportador de mercadorias de diversos tipos, principalmente commodities minerais, manufaturados e agrícolas (soja, laranja, cana de açúcar - açúcar e etanol e carne bovina).

Contudo, mesmo com esse quadro favorável e de estar vivendo uma fase de expansão econômica, ainda precisa ter uma política pública eficaz para distribuir a riqueza do país.

Comentários do WEF (2013-2014): houve uma ligeira deterioração em alguns dos indicadores macroeconômicos, um aumento no acesso ao financiamento e ausência 
de melhorias no funcionamento das instituições, preocupações crescentes sobre a eficiência do governo, corrupção e baixa confiança nos políticos. Além disso, a falta de progressos na melhoria da qualidade da infraestrutura geral e da educação, juntamente com uma economia ainda restrita à concorrência externa, também dificultam vantagem competitiva do Brasil.

Apesar desse cenário, o país ainda se beneficia de importantes pontos fortes, especialmente pelo seu tamanho no mercado, pelas qualidades das redes globais de negócio do país e das estratégias de operações individuais das empresas (sofisticação de negócios), com bolsas de excelência de inovação, muitas pautadas em pesquisas e atividades de alto valor agregado. Existe uma expectativa de que o Brasil não atrase as reformas necessárias para aumentar a sua competitividade e potencialize seus pontos fortes.

Os resultados do Brasil sobre a competitividade sustentável mantiveram-se estável em relação aos relatórios anteriores, embora perceba-se que sua sustentabilidade ambiental tenha tido uma avaliação um pouco mais positiva.

O tamanho do país e a riqueza de seus recursos naturais ativos apresentam resultados agregados relativamente positivos em áreas como as emissões e qualidade do ar. Além disso, a regulamentação ambiental tornou-se mais rigorosa por conta dos recentes esforços para desfazer o dano causado ao ambiente natural que ocorreram no processo de industrialização. No entanto, alguns problemas, tais como o desmatamento de longa duração, não parecem melhorar. O governo brasileiro divulgou números no início de 2014 apontando para novos desmatamentos na Amazônia, desfazendo o progresso recente na preservação da floresta tropical.

Em termos de sustentabilidade social, a elevada desigualdade de renda da população e a falta de acesso à saúde e saneamento estão prejudicando a capacidade do país de sustentar a sua competitividade. Protestos ocorridos em várias cidades do Brasil durante os meses de junho e julho de 2013, por conta da ineficiência e do alto custo do transporte público, aumentando os preços, em comparação aos níveis e salários, dificuldades de acesso ao crédito, combinado com fortes disparidades de renda, contribuíram com esse cenário, provocando as complexidades socioeconômicas e prejudicando a sustentabilidade social no país.

\subsubsection{ALEMANHA}

Considerado um país desenvolvido e a maior economia da Europa, a Alemanha possui uma extensão territorial de $357.021 \mathrm{~km}^{2}$, ocupa o $4^{\circ}$ lugar no ranking das maiores economias do mundo e também o $4^{\circ}$ lugar no Relatório de Competitividade Global (WEF 2013-2014).

A indústria alemã é altamente desenvolvida em função da tecnologia empregada e eficiência produtiva, e destacam-se os setores de serviços e finanças. Apesar da 
crise econômica mundial de 2008, a Alemanha se manteve firme. Principais setores econômicos: indústria (automóveis, química, medicamentos), tecnologia, finanças, construção civil, turismo e agricultura.

Comentários do WEF (2013-2014): é classificado como um excelente país, sendo o terceiro em qualidade de infraestrutura, proporcionando, em particular, instalações de primeira qualidade em todos os modais de transporte. O mercado de bens é bastante eficiente e é caracterizado por intensa competição local e baixa dominação no mercado pelas grandes empresas.

$\mathrm{Na}$ Alemanha, o setor empresarial é muito sofisticado, especialmente quando se trata de processos de produção e de canais de distribuição. As empresas alemãs estão entre as mais inovadoras do mundo, investindo fortemente em P\&D e exibindo uma alta capacidade de inovação, além de ainda apresentar uma desenvolvida capacidade de absorver as mais recentes tecnologias dentro das empresas. As suas instituições de pesquisas melhoraram sua qualidade em relação aos anos anteriores e seus cientistas e engenheiros parecem estar mais preparados. Todos esses atributos permitem que a Alemanha se beneficie imensamente do seu significativo tamanho de mercado, que se baseiam em seu mercado interno e a força de suas exportações.

Algumas deficiências permanecem em relação ao mercado de trabalho e ao sistema educacional. Apesar de algumas melhorias, o mercado de trabalho da Alemanha permanece o mesmo, em que a falta de flexibilidade na determinação dos salários e o alto custo de demissão dificultam a criação de novos empregos, especialmente durante a recessão do ciclo de negócios.

Para manter a Alemanha competitiva, no quesito de qualidade do sistema educacional, que nesse momento está em $23^{\circ}$ lugar e com o objetivo de ficar entre os dez principais países, deve-se melhorar os indicadores educacionais de qualidade da GCI, embora tenha sido observado uma melhoria em todos os indicadores, e isso é uma importante base para o crescimento induzido pela inovação sustentada.

$\mathrm{Na}$ questão da sustentabilidade social, a Alemanha tem um desempenho relativamente bom em ambos os aspectos. A taxa de desemprego entre os jovens é relativamente baixa, há amplo acesso aos cuidados de saúde e a presença de uma rede de segurança social são os principais impulsionadores da avaliação positiva. Algumas situações de dificuldades sociais vêm melhorando, como, por exemplo, o aumento do número de pessoas empregadas, que contavam com a ajuda do governo. A sustentabilidade ambiental também é relativamente positiva. As regulamentações rigorosas e a grande quantidade de terras protegidas indicam que o país dá atenção especial às essas questões. No entanto, apesar dos esforços do país, algumas questões permanecem inalteradas, como por exemplos, a intensidade de $\mathrm{CO} 2$ ainda é relativamente alta, embora venha diminuindo lentamente. 


\subsubsection{ESTADOS UNIDOS}

Considerado um país desenvolvido e a maior economia do mundo, os Estados Unidos possuem uma extensão territorial de $9.363 .520 \mathrm{~km}^{2}$, ocupa o primeiro lugar no ranking das maiores economias do mundo e o $5^{\circ}$ lugar no Relatório de Competitividade Global (WEF 2013-2014). A economia norte-americana funciona totalmente dentro dos parâmetros capitalistas. Com um mercado consumidor interno forte, além de também visar às exportações.

$\mathrm{O}$ país produz grande quantidade de gêneros agropecuários, destacando-se a produção de produtos industrializados e tecnologia. Principais setores econômicos: indústria, tecnologia, finanças, agricultura, mineração e turismo. Principais regiões industriais: sudeste, nordeste e costa leste, em destaque a Califórnia.

Comentários do WEF (2013-2014): depois de ter caído durante quatro anos consecutivos no ranking, os Estados Unidos recuperaram-se e ficaram em $5^{\circ}$ lugar no Relatório de Competitividade Global (WEF 2013-2014), o que mostra que a economia está voltando aos trilhos e destaca-se a recuperação, estabilidade e eficiência do país no mercado financeiro. Ao mesmo tempo, a avaliação das instituições públicas é um pouco mais positiva, resultando em uma expectativa melhor após anos de enfraquecimento da confiança nessa área.

Em geral, muitas características estruturais continuam contribuindo para que os Estados Unidos (EUA) sejam extremamente produtivos. Empresas norte-americanas são altamente sofisticadas e inovadoras, apoiadas por um excelente sistema universitário, que colabora admiravelmente com o setor empresarial em P, D \& I, combinando isso com um mercado de trabalho flexível e a criação de oportunidades, qualidades essas que fazem com que os EUA continuem muito competitivos.

Por outro lado, alguns pontos fracos em determinadas áreas permanecem. Embora a avaliação no pilar das instituições melhorou, a comunidade empresarial continua bastante crítica quanto à confiança nos políticos. Há preocupações sobre a capacidade do governo de manter os compromissos em relações ao setor privado e uma geral percepção de que o governo não gasta os recursos de forma correta, havendo desperdícios. O ambiente macroeconômico continua sendo a área mais fraca do país, embora o déficit diminuiu pela primeira vez desde o início da crise financeira.

O desempenho dos Estados Unidos em termos de competitividade sustentável manteve-se igual ao relatório anterior (2012-2013), provocando uma modesta melhora nos resultados de sustentabilidade social e ambiental. $\mathrm{O}$ resultado da sustentabilidade social é um pouco menor que a de outras economias avançadas, por causa da alta renda de desigualdade e desemprego relativamente alta entre os jovens. De acordo com a avaliação de 2012 do Census Bureau americano, mais de $16 \%$ da população viveu na pobreza nos Estados Unidos, um resultado pior do que a de 14,3\% de 2009 e um sinal da crescente polarização dentro da estrutura de renda. 
Na questão de sustentabilidade ambiental, o desempenho foi abaixo do esperado por consequência de vários fatores que incluem falta de compromisso do país de entrar em tratados internacionais, a sua falta de vontade política para melhorar a posição em questões ambientais críticas, a alta pressão sobre seus recursos hídricos na agricultura, suas emissões relativamente altos de $\mathrm{CO} 2$ e a proteção limitada de suas terras. Atrelados a isso, as preocupações destacadas pela Agência de Proteção Ambiental dos EUA (EPA), a necessidade de proteger os habitats, especialmente nas costas americanas, onde a urbanização está crescendo mais rápido. A EPA reconhece que há perda de terras e de florestas por causa de sua conversão em áreas urbanas ou para utilização agrícola, tornando-se uma ameaça significativa para os habitats naturais. Contudo, de uma forma mais positiva, a qualidade do ar está melhorando um pouco em diversas regiões do país.

\subsubsection{COREIA DO SUL}

Considerado um país emergente, a Coreia do Sul possui uma extensão territorial de $99.237 \mathrm{~km}^{2}$, ocupa o $15^{\circ}$ lugar no ranking das maiores economias do mundo e o $25^{\circ}$ lugar no Relatório de Competitividade Global (WEF 2013-2014). O sucesso econômico do país se deve às reformas econômicas, com ênfase na exportação e desenvolvimento de indústrias leves, enfatizados por meio de um sistema de laços íntimos desenvolvidos entre o governo e o setor privado, iniciado na década de 1960, que incluiu o crédito facilitado, restrição às importações, subsídios a determinados setores e incentivo ao trabalho.

O país também promoveu uma reforma financeira, ajustando as instituições e introduziu planos econômicos flexíveis. Nos anos da década de 1970 começou a destinar recursos para as indústrias pesadas, químicas, eletrônicas e de automóveis, dando continuidade nas décadas seguintes. A Coreia do Sul implantou uma ampla reestruturação de sua política econômica e de seus conglomerados (chaebols) após a crise financeira de 1998, salda antecipadamente as dívidas com o FMI e inicia a retomada da taxa de crescimento do PIB. Principais setores econômicos: indústria, tecnologia, finanças e informática.

Comentários do WEF (2013-2014): a Coreia do Sul possui um notável ambiente macroeconômico, além da infraestrutura e sistema educacional excelentes. As taxas de matrícula em todos os níveis da educação estão entre os mais altos do mundo. Esses fatores, combinados com alto grau de adoção tecnológica do país e relativamente forte sofisticação de negócios, contribuem para explicar a capacidade ímpar do país em inovação. No entanto, sua avaliação é enfraquecida pela qualidade média de suas instituições públicas e privadas, a extrema rigidez e as ineficiências do seu mercado de trabalho, além do mau funcionamento do mercado financeiro. Dessa forma, o país deverá abordar essas questões de forma decisiva e firme, melhorando seu diferencial 
competitivo, principalmente em relação aos demais "tigres asiáticos" (Cingapura, Taiwan - República da China e Hong Kong).

O relatório de Competitividade Global (WEF) não faz comentários sobre as sustentabilidades sociais e ambientais da Coreia do Sul.

\subsection{5 ÍNDIA}

Considerado um país emergente, a Índia possui uma extensão territorial de $3.287 .590 \mathrm{~km}^{2}$, ocupa o décimo lugar no ranking das maiores economias do mundo e o $60^{\circ}$ lugar no Relatório de Competitividade Global (WEF 2013-2014). É um dos países integrantes dos BRICS. Possui uma economia diversificada, apresentando fortes resultados nas áreas agrícola, industrial, tecnológica, financeira e de serviços, e destaque nas exportações de produtos manufaturados. A indústria de tecnologia também tem apresentado forte crescimento nos últimos anos. A mão de obra barata e especializada tem estimulado as instalações de filiais de empresas de tecnologia estrangeiras. $\mathrm{Na}$ área de serviços pode-se destacar a expansão da produção de softwares.

Contudo, o aspecto social é um dos principais problemas da economia da Índia, devido à forte concentração de renda que gera desigualdades sociais e econômicas, e a maioria dos trabalhadores receberem baixos salários com exaustivas jornadas de trabalho. Principais setores econômicos: agricultura, indústria, tecnologia, finanças.

Comentários do WEF (2013-2014): com uma pontuação GCI (Global Competitive Index) essencialmente inalterada desde 2009 e com tendência de queda. A Índia continua sendo penalizada pelo seu desempenho decepcionante nos pilares básicos subjacentes da competitividade. A oferta de transporte do país, as TICs e a infraestrutura de energia continuam a ser largamente insuficientes e mal adaptadas às necessidades da economia, apesar da implantação da melhoria constante desde 2006. Os empresários indianos comentam repetidamente que a infraestrutura é o maior obstáculo à realização de negócios, à frente da corrupção e da pesada burocracia.

Não obstante as melhorias em todos os pilares ao longo dos últimos anos, os níveis de saúde pública e de educação ainda são muito pobres e continuam a ser a causa principal da baixa produtividade da Índia. A qualidade da educação superior é melhor, mas suas taxas de matrículas permanecem muito baixas, até mesmo para padrões em países emergentes. Referente às instituições do país, o descontentamento dentro do ambiente empresarial permanece elevado por causa da falta de reformas e da incapacidade do governo de resolvê-las. A confiança pública nos políticos está se desgastando desde 2009, e a utilização de propinas continuam profundamente enraizadas.

O ambiente macroeconômico também teve a sua situação deteriorada, a taxa de inflação e taxa de déficit público em relação ao PIB chegaram perigosamente perto de dois dígitos em 2012. De fato, uma pesquisa com analistas sobre a dívida pública, em 
março de 2013, revela um aumento do risco de não cumprimento dos pagamentos sobre o ano anterior. Outra grande preocupação é o baixo nível de prontidão tecnológica, embora as empresas adotem, de forma relativa, novas tecnologias, as taxas de penetração da Internet e de telefonia fixas e móveis entre a população, permanecem entre as menores dos países emergentes na Ásia. Além disso, a situação piorou em termos de eficiência do mercado de trabalho, e o problema mais evidente ainda é o número pífio na participação das mulheres na força de trabalho. No mundo árabe, a Índia tem a menor percentagem de mulheres, em relação aos homens, que trabalham fora.

A competitividade sustentável da Índia é também caracterizada por preocupações em ambas as áreas de sustentabilidade. No lado da sustentabilidade social, o desempenho da Índia é prejudicado pela falta de acesso ao saneamento básico e aos serviços de saúde para muitos de seus cidadãos (apenas 35\% da população têm acesso a saneamento básico). Além disso, apesar da introdução de Programas de Assistência Social Nacional (NSAP) em 1995, a proporção da população coberta pela rede de segurança social ainda é relativamente pequena. Essa questão, combinada com um grande setor informal e uma elevada percentagem da força de trabalho em empregos temporários, faz com que seja difícil gerir o crescimento da desigualdade de renda do país. No total, essas questões estruturais fazem a competitividade da Índia ficar vulnerável a choques.

O desempenho ambiental da Índia também dificulta a realização de competitividade sustentável, provocado por um alto nível de emissões de gazes, especialmente em termos de concentração de material específico, e há, ainda, falta de qualidade de meio ambiente natural em algumas áreas protegidas. Atrelado a isso, a alta intensidade do uso da água no setor agrícola está esgotando os reservatórios, pois o seu uso está acima da sua capacidade de renovação. A utilização nos setores agrícola e industrial, o aumento da população, as lacunas na infraestrutura e o aumento da contaminação, provocam a escassez da água.

\subsubsection{RÚSSIA}

Considerado um país emergente, a Rússia possui uma extensão territorial de 17.075.400 $\mathrm{km}^{2}$, ocupa o $8^{\circ}$ lugar no ranking das maiores economias do mundo, embora especialistas afirmem que em 2014 tomará o $7^{\circ}$ lugar do Brasil, devido à desaceleração econômica e a desvalorização da moeda brasileira (Real), está em $64^{\circ}$ lugar no Relatório de Competitividade Global (WEF 2013-2014). Também é um dos países integrantes dos BRICS. Após o colapso da União Soviética (1991), a Rússia busca estabelecer uma economia de mercado moderna e vem conseguido altas taxas de crescimento econômico.

Embora tenha passado por uma crise financeira em agosto de 1998 quando 
anunciou a desvalorização do rublo e uma moratória, que inicialmente teria noventa dias de interrupção nos pagamentos externos, logo em 1999, a economia russa começou a se recuperar, mantendo um ritmo de crescimento econômico acelerado. No entanto, diante da crise mundial em 2008 e a queda dos preços do petróleo, as perspectivas para 2009 foram pessimistas.

A Rússia integra a área da APEC (Asia-Pacific Economic Cooperation), um bloco econômico que tem por objetivo transformar o Pacífico em uma área de livre comércio e que engloba economias asiáticas, americanas e da Oceania. Principais setores econômicos: indústria, mineração (principalmente petróleo e gás natural), finanças e agricultura.

Comentários do WEF (2013-2014): na Rússia, o ambiente macroeconômico continua melhorando com a diminuição da dívida do governo e a manutenção do superávit orçamentário. Outros pontos fortes incluem seu alto nível de escolaridade, especialmente no nível superior, sua infraestrutura muito boa e o seu grande mercado interno, que representam as áreas que podem ser aproveitadas para melhorar a competitividade da Rússia. Por outro lado, o campo continua recebendo uma má avaliação, por conta da ausência das suas instituições públicas e apresenta falta de capacidade de inovação.

A Rússia sofre de ineficiências nos seus produtos, no mercado de trabalho e no mercado financeiro. O fraco nível de concorrência, causada pela incapacidade e restrições contra políticas de monopólio e da alta no comércio de produtos estrangeiros, e a falta de confiança no sistema financeiro, contribuíram para a incompetência da alocação dos seus recursos, prejudicando os níveis mais elevados de produtividade na economia. Além disso, como o país caminha em direção a um estágio mais avançado das economias emergentes, a sua falta de sofisticação de negócios e as baixas implantações tecnológicas, podem se tornar cada vez mais importantes nos desafios para a progressão de sua sustentabilidade.

Em termos de sustentabilidade social, a Rússia é caracterizada por uma relativamente fraca rede de segurança social, com elevada e crescente desigualdade e limitações na mobilidade social. Em termos de sustentabilidade do meio ambiente, suas leis ambientais são fracas, a gradativa ausência de qualidade e o esgotamento de seus recursos naturais surgem como os mais importantes desafios para a liderança do país. Contudo, o país é dotado de ricos recursos naturais, incluindo uma das maiores reservas de água e de florestas diversificadas. A consequência é que o país ainda funciona relativamente bem em vários indicadores ambientais na comparação internacional, apesar da falta de planejamento eficaz na utilização desses recursos. 


\subsubsection{CHINA}

Considerado um país emergente, a China possui uma extensão territorial de $9.596 .961 \mathrm{~km}^{2}$, ocupa o $2^{\circ}$ lugar no ranking das maiores economias do mundo e o $29^{\circ}$ lugar no Relatório de Competitividade Global (WEF 2013-2014), além de ser considerado também um dos países integrantes dos BRICS. As suas principais características são: economia globalizada a partir da década de 1990 e abertura da economia para a entrada do capital internacional; é o maior produtor mundial de alimentos; agricultura mecanizada; incentivos governamentais e investimentos na área de educação (principalmente ensino técnico), em infraestrutura, nas áreas de mineração e na produção de tecnologia; controle governamental dos salários e regras trabalhistas, resultando em um custo reduzido com mão de obra, tornando os produtos chineses os mais baratos do mundo.

A China é um dos maiores importadores mundiais de matéria prima. Assim como a Rússia, a China também participa da APEC (Asian Pacific Economic Cooperation). Mesmo após sentir os abalos da crise mundial em 2008, a China conseguiu se manter com um PIB mais elevado comparado às outras economias mundiais. Com todo esse crescimento, é certo que problemas surgiriam. O forte crescimento econômico dos últimos anos gerou empregos, renda e crescimento das empresas chinesas, mas aumentaram a inflação. Grande parte da população ainda vive em situação de pobreza, principalmente no campo.

A utilização em larga escala de combustíveis fósseis (carvão mineral e petróleo) tem gerado um grande nível de poluição do ar, prejudicando também os rios. Os salários, controlados pelo governo coloca os operários chineses entre os que recebem uma das menores remunerações do mundo.

Comentários do WEF (2013-2014): a China possui uma larga vantagem em relação às economias denominadas BRICS. No relatório da WEF 2013-2014, ficou em $29^{\circ}$, bem à frente da África do Sul $\left(53^{\circ}\right)$, Brasil $\left(56^{\circ}\right)$, Índia $\left(60^{\circ}\right)$ e Rússia $\left(64^{\circ}\right)$.

As instituições na China apresentaram uma leve melhora, mas ainda possuem fragilidades, incluindo corrupção, questões de segurança, baixos níveis de prestações de contas, padrões éticos nos negócios. Além disso, problemas em suportar segmentos de mercado que estão se tornando cada vez mais importante para China, tornando-a mais rica e não podendo mais contar com mão de obra barata. $\mathrm{O}$ seu mercado financeiro é prejudicado pela a relativa fragilidade do setor bancário e a adoção tecnológica por parte das empresas e pela população ainda continuar muito baixa.

A eficiência do seu mercado de bens foi seriamente afetada por várias barreiras com regras de entradas e de investimentos, o que limita fortemente a competição. $\mathrm{O}$ seu ambiente macroeconômico permanece favorável. A inflação diminuiu, o déficit orçamentário está moderado, sua dívida pública em relação ao PIB está entre uma das menores do mundo e a taxa de poupança bruta representa $50 \%$ do seu PIB. No 
entanto, essa taxa é demasiadamente elevada, levando em conta a necessidade de adequar a sua economia para os investimentos e para aumentar o consumo.

Embora a China receba boas notas na saúde e na educação básica, a avaliação é mais negativa quando se trata de ensino superior, por causa da baixa taxa de matrículas, provocando uma qualidade média do ensino e uma aparente desconexão entre o conteúdo educacional e as necessidades dos negócios. Por fim, a capacidade de inovação da China vem melhorando recentemente, mas ainda há muito por fazer para que ela se torne uma potência em inovação.

Em termos de sustentabilidade social, a China tem desempenho comparável a sua competitividade global, embora isso possa ser afetado pelo fato de que o país não informa dados relacionados com o desemprego dos jovens ou do emprego precário. $\mathrm{O}$ acesso à água potável e saneamento melhoraram ligeiramente, o acesso aos cuidados de saúde e algum acesso a rede de segurança social. No entanto, apenas uma parte da população é coberta pelo sistema de saúde e se restringe principalmente aos trabalhadores da cidade de tempo integral. $35 \%$ da população ainda não tem acesso às melhorias no saneamento básico. Além disso, a desigualdade de renda é alta, com fortes diferenças entre as regiões do país e também dentro das cidades. Essa situação tem levado o governo a considerar o aumento do salário mínimo nacional para 40\% dos salários urbanos médios em 2015.

É, no entanto, na questão da sustentabilidade ambiental que a competitividade da China pode deparar com os desafios mais importantes, porém, esse componente é particularmente menos positivo. O nível das emissões de dióxido de carbono continua a subir e a poluição do ar está piorando em várias cidades. O setor agrícola coloca uma grande pressão sobre o meio ambiente, por exemplo, e a intensidade do uso de água na China é muito alta. A poluição da água também é generalizada, com o ecossistema dos cursos das águas severamente danificados. A rápida industrialização teve um custo pesado sobre o meio ambiente chinês, especialmente em termos de poluição e, de acordo com um estudo da Academia Chinesa de Planejamento Ambiental, com sede em Pequim, as questões de saúde, degradação da cultura e as perdas com acidentes relacionadas à poluição reduziram a produtividade da China, com o custo total decorrentes da poluição estimado em 3,1\% do PIB.

A deterioração tangível dos recursos naturais tem forçado o governo a planejar mudanças nas questões tributárias e uma das ações é alterar a tributação do carvão com o objetivo de desestimular a utilização desse produto. Além disso, a China pode introduzir imposto no uso da água. O crescente foco da liderança chinesa sobre o meio ambiente será importante para colocar o país em um caminho mais sustentável ao longo dos próximos anos. 


\subsection{8 ÁFRICA DO SUL}

Considerado um país emergente, a África do Sul possui uma extensão territorial de $1.221 .037 \mathrm{~km}^{2}$, ocupa o $27^{\circ}$ lugar no ranking das maiores economias do mundo e o $53^{\circ}$ lugar no Relatório de Competitividade Global (WEF 2013-2014), e é considerado um dos países integrantes dos BRICS. Possui uma economia de mercado e é a mais desenvolvida do continente africano, representando cerca de $25 \%$ do PIB do continente. Tem recebido nesses últimos anos investimentos de capitais internacionais.

A realização da Copa do Mundo em 2010 colaborou para o crescimento econômico do país, principalmente nos setores de construção e infraestrutura. Principais setores econômicos: indústria, mineração (ouro, platina, cromo, diamantes), turismo e finanças. Contudo, há problemas sociais graves, em destaques: a fome, problemas de desnutrição de crianças, o número elevado de desempregados, alto número de analfabetismo, epidemia de AIDS, mortalidade infantil, guerras e conflitos.

Comentários do WEF (2013-2014): a África do Sul adotou boas medidas em relação a qualidade de suas instituições, incluindo a proteção e direitos da propriedade intelectual, com eficiência dos seus aspectos legais. A alta responsabilidade de suas instituições privadas contribuiu positivamente para o quadro institucional. Além disso, o mercado financeiro da África do Sul continua se desenvolvendo, ocupando o impressionante terceiro lugar do relatório.

O país também tem um mercado de bens e serviços eficientes e vai razoavelmente bem em áreas mais complexas, como a sofisticação de negócios e inovação. Contudo, os fortes laços do país com economias avançadas, principalmente na zona do euro, tornam-no mais vulnerável à desaceleração econômica e tem contribuído para a deterioração dos indicadores fiscais.

O seu desempenho no ambiente macroeconômico caiu drasticamente, a percepção de desperdícios dos gastos do governo e uma desconfiança generalizada nos políticos permanecem preocupantes, bem como a ausência de segurança continua sendo uma área de grande preocupação para se fazer negócios. Construir uma força de trabalho qualificada e criar empregos suficientes também são desafios a serem enfrentados. Os resultados das altas taxas de doenças transmissíveis e indicadores de saúde insatisfatórias são as mais comuns.

A qualidade do sistema educacional é muito fraca, com baixas taxas de matrículas no ensino primário e no ensino superior. A eficiência do mercado de trabalho também é fraca, as práticas de contratação e demissão são extremamente rígidas, as empresas não definem os salários de forma flexível e existem tensões significativas nas relações de trabalho pelo empregador. Elevar os padrões de ensino e tornar o mercado de trabalho mais eficiente é fundamental, tendo em vista a alta taxa de desemprego do país, mais de $20 \%$, com a taxa de desemprego entre os jovens estimado em cerca de $50 \%$.

A sustentabilidade social da África do Sul é prejudicada pela alta desigualdade de 
renda e o alto número de desemprego dos jovens. Além disso, o país ainda não atingiu o acesso universal ao saneamento básico. Em uma nota mais positiva, a participação da população no emprego temporário é relativamente baixa e é um pouco melhor do que muitos outros países em estágio similar de desenvolvimento.

Do ponto de vista ambiental, a África do Sul tem seu desempenho enfraquecido, principalmente por meio do aumento de emissões de dióxido de carbono e das baixas reservas de água e de peixes. A erosão e práticas relacionadas com a utilização do solo para a agricultura, como por exemplo, o uso de pesticidas, contribui para aumentar a poluição no meio ambiente. 
